\title{
Ion Exchange Removal of Strontium from Simulated and Actual N-Springs Well Water at the Hanford 100-N Area
}

\author{
G. N. Brown \\ K. J. Carson \\ J. R. DesChane \\ R. J. Elovich \\ T. M. Kafka ${ }^{(a)}$ \\ L. R. White ${ }^{(\mathrm{a})}$
}

June 1996

Prepared for

the U.S. Department of Energy

under Contract DE-AC06-76RLO 1830

Pacific Northwest National Laboratory

Richland, WA 99352

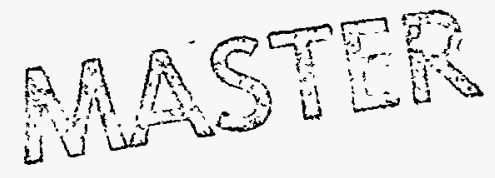

(a) 3M Company, St. Paul, Minnésota. 


\section{DISCLAIMER}

This report was prepared as an account of work sponsored by an agency of the United States Government. Neither the United States Government nor any agency thereof, nor any of their employees, make any warranty, express or implied, or assumes any legal liability or responsibility for the accuracy, completeness, or usefulness of any information, apparatus, product, or process disclosed, or represents that its use would not infringe privately owned rights. Reference herein to any specific commercial product, process, or service by trade name, trademark, manufacturer, or otherwise does not necessarily constitute or imply its endorsement, recommendation, or favoring by the United States Government or any agency thereof. The views and opinions of authors expressed herein do not necessarily state or reflect those of the United States Government or any agency thereof. 


\section{DISCLAIMER}

Portions of this document may be illegible in electronic image products. Images are produced from the best available original document. 


\section{Summary}

Pacific Northwest National Laboratory (PNNL), ${ }^{(a)}$ in conjunction with 3M; AlliedSignal, Inc.; Bechtel Hanford Inc. (BHI); and CH2M Hill, conducted this study as part of the Efficient Separations and Processing Crosscutting Program. The study's purpose was to assess the performance of the $3 \mathrm{M}$ Process Absorber Development Unit (PADU) and the sodium nonatitanate (NaTi) material produced by AlliedSignal for removing strontium from simulated and actual ground water from the Hanford $\mathrm{N}$-Springs Pump and Treat Demonstration Facility. The objective of these experiments was to determine the strontium-loading breakthrough profiles of actual and simulated ground waters by ion exchange using a proprietary $3 \mathrm{M}$ engineered material (termed $\mathrm{NaTi} / \mathrm{WWL}$ ) in either disk or cartridge forms. Specific experimental objectives included 1) demonstrating the PADU as a viable cartridge test unit; 2) generating complete strontium, calcium, and magnesium breakthrough curves for the cartridge and disk tests; 3) demonstrating strontium decontamination to meet drinking-water standards; and 4) verifying simulant performance.

Experiments were completed using actual and simulated $\mathrm{N}$-Springs ground water and either $18 \mathrm{~cm}$. cartridges (100-g NaTi/WWL, 0.163-L bed volume (BV) each) or 2.5-cm disks (0.59-g NaTi/WWL, $0.98-\mathrm{mL} \mathrm{BV}$ ) of NaTi/WWL web. Simulants were developed based on available analytical data. The laboratory disk studies were completed using the following process steps: 1) web preparation in caustic, 2) loading at neutral $\mathrm{pH}, 3$ ) elution with $0.5 \mathrm{M} \mathrm{HNO}_{3}, 4$ ) water wash, 5) caustic regeneration, and 6) water rinse. Laboratory and field cartridge studies were undertaken in the loading mode (steps 1 and 2) only. The following results were obtained in this study:

- BHI personnel successfully operated the 3M PADU at the N-Springs Pump and Treat Facility. Although minor system difficulties were encountered, the effectiveness of the NaTi/WWL membrane in removing strontium from Hanford ground water was demonstrated.

- Laboratory testing of small-scale disks and process-scale cartridges using simulated and actual ground water effectively predicted the field performance of the PADU. Approximately $1000 \mathrm{BV}$ of solution could be processed before reaching a $\mathrm{Sr} C / \mathrm{C}_{0}$ of 0.5 , where $\mathrm{C}_{0}$ is equal to $1.49 \mathrm{E}-6 \mathrm{M} \mathrm{Sr}$. The data suggest that accurate scale-up of process performance data from laboratory disk tests to fullscale cartridge systems is likely. Complete loading breakthrough curves were generated for barium, calcium, magnesium, and strontium.

- The disk loading (mmol Sr per gram or milliliter of resin) of the NaTi/WWL was calculated to be $2.61 \mathrm{E}-03 \mathrm{mmol} / \mathrm{g}(1.57 \mathrm{E}-03 \mathrm{mmol} / \mathrm{mL})$ for the actual N-Springs water. Elution was accomplished with $0.5 \mathrm{M} \mathrm{HNO}_{3}$ at $7.5 \mathrm{BV} / \mathrm{min}$ and required $80 \mathrm{BV}$ to reach $0.1 \mathrm{Sr} \mathrm{C} / \mathrm{C}_{0}$.

(a) Pacific Northwest National Laboratory is operated for the U.S. Department of Energy by Battelle . under Contract DE-ACO6-76RLO 1830. 
- During the field demonstration, the PADU cartridge loading (mmol/g) was determined to be 2.84E-04, 8.68E-01, 7.58E-02, and 2.85E-03 for barium, calcium, magnesium, and strontium, respectively. In addition, $1.78 \mathrm{E}+00 \mathrm{mmol} \mathrm{Na} / \mathrm{g}$ was released during loading, effectively confirming the mass balance.

- The strontium breakthrough curves described in this report were nearly identical irrespective of solution (simulated and actual ground water), geometry of the ion exchange material (disks or cartridges), or material volume (single or multiple cartridges), and indicate an ability to mimic strontium ion exchange with the intelligent formulation of nonradioactive simulant solutions. 


\section{Acknowledgments}

Pacific Northwest National Laboratory (PNNL) is collaborating with universities, national laboratories, and industry to develop and test new materials for the pretreatment of nuclear process wastes and ground waters at Hanford. This work has been performed under the direction of the U. S. Department of Energy's Office of Science and Technology. The experimental work described in this report would not have been possible without the encouragement and resources provided by the Efficient Separations and Processing (ESP) Crosscutting Program. A special recognition is due to Mr. Lane A. Bray, formerly the Principal Investigator for the Develop and Test Sorbers task at PNNL. In addition, the authors would like to acknowledge the contributions to this effort of D. R. Baker, D. L. Bowers, A. I. Davis, J. A. Kion, T. E. Moody, B. Mukherjee, and N. A. Puckett of Bechtel Hanford Incorporated (BHI); D. J. Vaught (CH2M Hill); B. M. Mauss and D. E. Olson of the U.S. Department of Energy Richland Operations; W. F. Bonner and W. L. Kuhn (PNNL); D. Boggs, K. Carlson, T. Fredrickson, D. Seely, I. ShawEpperson, N. Stern, and E. Wisted at 3M (St. Paul, MN); and S. F. Yates (AlliedSignal). This work was performed jointly by researchers at $3 \mathrm{M}, \mathrm{BHI}$, and PNNL. 
. 


\section{Contents}

Summary $\ldots \ldots \ldots \ldots \ldots \ldots \ldots \ldots \ldots \ldots \ldots \ldots \ldots \ldots \ldots \ldots \ldots$ iii

Acknowledgments $\ldots \ldots \ldots \ldots \ldots \ldots \ldots \ldots \ldots \ldots \ldots \ldots \ldots \ldots$

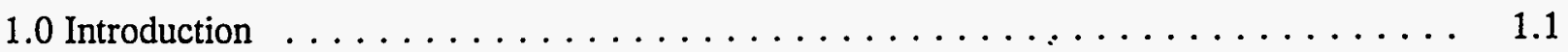

1.1 Background $\ldots \ldots \ldots \ldots \ldots \ldots \ldots \ldots \ldots \ldots \ldots \ldots \ldots \ldots \ldots \ldots \ldots$

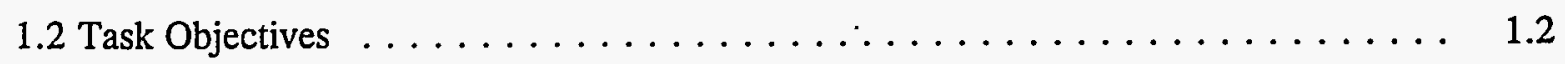

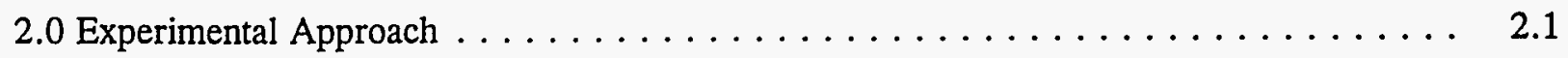

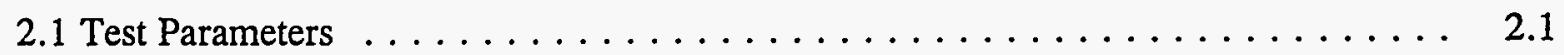

2.2 Ion Exchange Distribution $\ldots \ldots \ldots \ldots \ldots \ldots \ldots \ldots \ldots \ldots \ldots \ldots \ldots \ldots \ldots \ldots \ldots$

2.3 Preliminary Disk Tests . . . . . . . . . . . . . . . . . 2.4

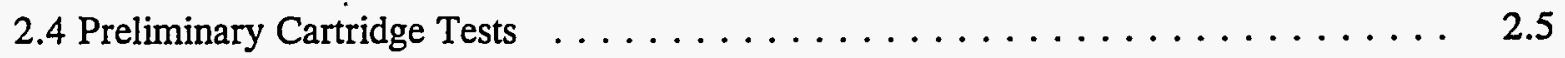

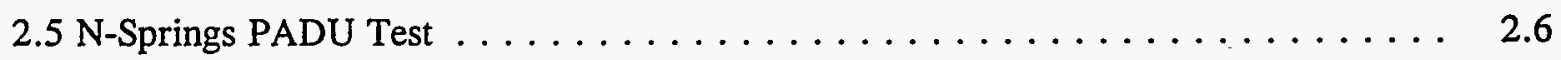

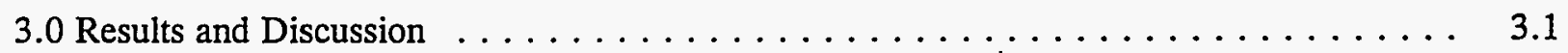

3.1 Strontium Loading Comparison $\ldots \ldots \ldots \ldots \ldots \ldots \ldots \ldots \ldots \ldots \ldots$

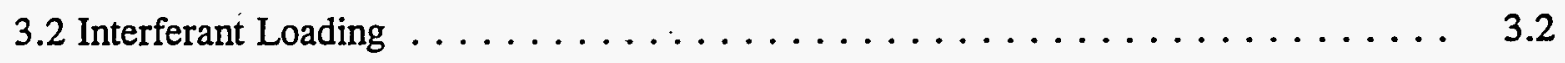

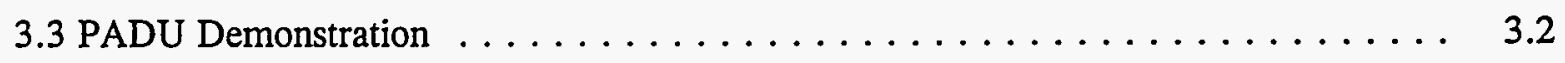

3.4 Ion Exchange Loading Capacity $\ldots \ldots \ldots \ldots \ldots \ldots \ldots \ldots \ldots \ldots \ldots \ldots \ldots \ldots \ldots$

4.0 Conclusions $\ldots \ldots \ldots \ldots \ldots \ldots \ldots \ldots \ldots \ldots \ldots \ldots \ldots \ldots \ldots \ldots \ldots \ldots \ldots \ldots$

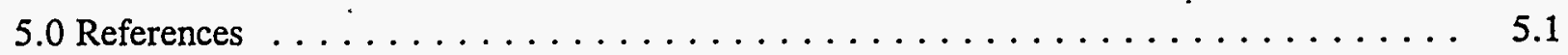

Appendix: Laboratory Data $\ldots \ldots \ldots \ldots \ldots \ldots \ldots \ldots \ldots \ldots \ldots \ldots \ldots \ldots$ 


\section{Figures}

2.1 Schematic Diagram of the Laboratory Disk Filtration Apparatus . . . . . . . . . 2.4

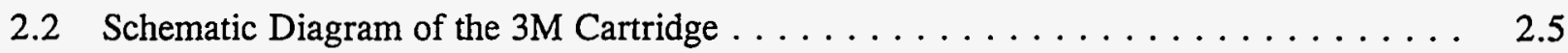

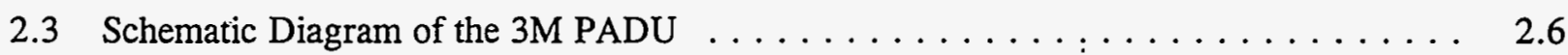

2.43 M PADU Used at Hanford $N$-Springs $\ldots \ldots \ldots \ldots \ldots \ldots \ldots \ldots \ldots \ldots$

3.1 Comparison of Strontium Breakthrough Curves for NaTi/WWL Disks and Cartridges in Simulated and Actual Ground Water from Hanford N-Springs $\ldots \ldots \ldots \ldots \ldots . . \ldots$

3.2 Calcium, Magnesium, and Strontium Breakthrough Curves for a Laboratory-Scale $\mathrm{NaTi} / \mathrm{WWL}$ Cartridge in Simulated Ground Water from Hanford N-Springs . . . . . 3.3

3.3 Calcium, Magnesium, and Strontium Breakthrough Curves for a NaTi/WWL Cartridge in Actual Ground Water During the Third Sequence of Hanford N-Springs

PADU Demonstration $\ldots \ldots \ldots \ldots \ldots \ldots \ldots \ldots \ldots \ldots \ldots \ldots$

3.4 Strontium Breakthrough Curves During PADU Sequencing at Hanford N-Springs $\ldots \ldots \quad 3.5$ 


\section{Tables}

2.1 Comparison of Experimental Test Conditions for the PNNL Laboratory Disk Test, the 3M Laboratory Cartridge Test, and the N-Springs PADU Demonstration . . . . . . 2.2

2.2 Analytical Results for the Composition of $3 \mathrm{M}$ Simulant and Actual N-Springs

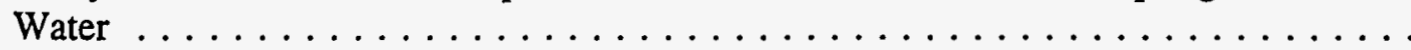

3.1 Alkaline Metal Loading of the PADU NaTi/WWL Web with Actual

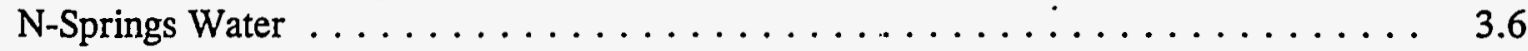

A.1 ICP-AES Instrument Characteristics and Performance $\ldots \ldots \ldots \ldots \ldots \ldots \ldots$ A.1

A.2 Strontium Loading Data for PNNL Disk Test Using Actual N-Springs Water . . . . . A.2

A.3 Strontium Elution Data for PNNL Disk Test Using Actual N-Springs Water $\ldots \ldots$. . A.3

A.4 Strontium Loading Data for PADU Cartridge Field Demonstration at N-Springs . . . . . A.3

A.5 Barium Loading Data for PADU Cartridge Field Demonstration at N-Springs $\ldots \ldots$ A.4

A.6 Calcium Loading Data for PADU Cartridge Field Demonstration at N-Springs $\ldots \ldots$ A.4

A.7 Magnesium Loading Data for PADU Cartridge Field Demonstration at

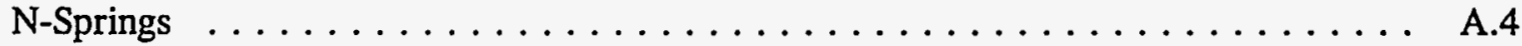

A.8 Sodium Loading Data for PADU Cartridge Field Demonstration at N-Springs . . . . . A.5

A.9 Strontium Loading Data for 3M Laboratory Cartridge Test Using Simulant $\ldots \ldots$. . . . A.5

A.10 Calcium Loading Data for 3M Laboratory Cartridge Test Using Simulant . . . . . . . . A.6

A.11 Magnesium Loading Data for 3M Laboratory Cartridge Test Using Simulant . . . . . . A.6

A.12 Sodium Loading Data for 3M Laboratory Cartridge Test Using Simulant $\ldots \ldots$. . . A.7

A.13 Strontium-90 Loading Data for PADU Cartridge Field Demonstration at N-Springs _. . A.7 


\subsection{Introduction}

Experimental ion exchange studies are being conducted by the Pacific Northwest National Laboratory (PNNL) ${ }^{(a)}$ under the Efficient Separations and Processing (ESP) Crosscutting Program to evaluate newly emerging materials (Bray et al. 1990; Bray et al. 1993; Brown et al. 1995a; Brown et al. 1996) and technologies for removing cesium, strontium, cobalt, technetium, and transuranic elements (TRUs) from simulated and actual wastes at Hanford. Previous work (Bray et al. 1984; Brown et al. 1995b; Brown et al. 1995c) focused on applications to treat high-level alkaline tank wastes, but many of the technologies can also be applied in process and ground-water remediation (Herbst et al. 1995). Ultimately, each process must be evaluated in terms of life-cycle costs, removal efficiency, process chemical consumption and recycle, stability of materials exposed to chemicals and radiation, compatibility with other process streams, secondary waste generation, process and maintenance costs, and final material disposal.

This report assesses the performance of the 3M-designed Process Absorber Development Unit. (PADU) and the AlliedSignal-produced sodium nonatitanate (NaTi) material in removing trace quantities of strontium from simulated and actual Hanford N-Springs ground water. The experimental objective was to determine the strontium-loading breakthrough profile of a proprietary $3 \mathrm{M}$-engineered material (termed $\mathrm{NaTi} / \mathrm{WWL}$ ) in either disk or cartridge forms.

\subsection{Background}

Hanford's 100-N Area N-Springs well water (from wells 199-N-106A, 199-N-14, and 199-N-75) is known to be contaminated with traces of radioactive strontium- 90 and tritium-3. Other radionuclides and organic and inorganic species have been detected, but generally exist at levels below federal drinking-water standards (Dirkes 1990; Hartman and Lindsey 1993). Strontium-90 levels vary between 1000 and $2000 \mathrm{pCi} / \mathrm{L}$, depending upon the water table level. Tritium concentrations are normally about $60,000 \mathrm{pCi} / \mathrm{L}$. In addition, the ground water contains high concentrations of nonradioactive strontium $(0.13 \mathrm{ppm})$, calcium ( $30 \mathrm{ppm})$, and magnesium ( $5 \mathrm{ppm})$, the presence of which frustrates efforts to remediate the strontium-90 using ion exchange technologies. The major anionic component of the ground water is carbonate.

The N-Springs Pump and Treat Demonstration Facility is currently processing ground water from the $100-\mathrm{N}$ Area wells at $189.3 \mathrm{~L} / \mathrm{min}$ (50 gallons per minute [gpm]) using conventional ion exchange technology. The present system consists of four columns, each capable of holding $65 \mathrm{ft}^{3}$ of a natural zeolite, clinoptilotite. Normally, three columns are connected in series, with the fourth held off-line for disposal and installation of the spent exchanger. The system is typically operated continuously at 189.3 $\mathrm{L} / \mathrm{min}(50 \mathrm{gpm})$ for 2 weeks and then the lead column is removed from service. The column

(a) Pacific Northwest National Laboratory is operated for the U.S. Department of Energy by Battelle under contract DE-ACO6-76RLO 1830. 
previously held in reserve is then placed in service at the end or trailing position and solution processing is continued. Strontium is removed by the ion exchanger to levels below federal drinking-water standards of $40 \mathrm{pCi} / \mathrm{L}$. However, the process generates a large amount of solid radioactive waste. Bechtel Hanford Inc. (BHI) operators and engineers are searching for methods to improve the process and reduce the amount of secondary waste.

\subsection{Task Objectives}

The overall objectives of this task are to 1) develop and evaluate newly conceived materials for recovering radionuclides from process wastes, 2) determine loading and elution efficiency of the materials, 3) determine the materials' physical life cycle (including stability when exposed to radiation and chemicals), and 4) determine if basic ion exchange data can be applied to a broad range of chemical compositions. The goal of this subtask was to determine the loading of barium, calcium, magnesium, and strontium on $3 \mathrm{M}$ WWL webs that contain NaTi in actual and simulated Hanford N-Springs ground water. 


\subsection{Experimental Approach}

The removal of strontium from actual and simulated ground water using an engineered form of sodium nonatitanate ( $\mathrm{NaTi}$, AlliedSignal, Des Plaines, IL) was investigated in three separate tests. In the first test, a small-scale laboratory disk loading experiment was completed at PNNL using actual $\mathrm{N}$-Springs water containing approximately $1100 \mathrm{pCi} / \mathrm{L}$ strontium-90. The water was collected from well 199-N-106A on 11/1/95, 11:10AM. In the second test, a single cartridge loading experiment was completed at $3 \mathrm{M}$ (St. Paul, MN) using a simulated ground-water composition designed to mimic the $\mathrm{N}$-Springs ground water. The final test was completed at the $\mathrm{N}$-Springs Pump and Treat Demonstration Facility on January 25, 1996, using the PADU, a skid-mounted cartridge-based system designed by $3 \mathrm{M}$ and operated by $\mathrm{BHI}$ personnel.

\subsection{Test Parameters}

Table 2.1.compares the experimental parameters used in each of the three tests, and Table 2.2 compares the actual and simulated ground-water chemical compositions. Inductively coupled plasma (ICP) analysis of the nonradioactive strontium was used as an analytical method for the $3 \mathrm{M}$ simulant and $\mathrm{N}$-Springs PADU cartridge tests. In addition, to confirm the ICP results for strontium, strontium-90 beta analysis was completed on selected samples obtained from the N-Springs PADU demonstration. For the PNNL disk test, radioactive strontium- 85 tracer was added to the water and was measured by gamma energy analysis (GEA). All material calculations were based on the mass of the entire NaTi/WWL web and did not account for the percentage of active particle in the web.

In general, the purpose of the laboratory tests was to estimate the strontium loading characteristics of the adsorbent material before conducting the actual N-Springs PADU demonstration. Therefore, an accurate comparison of the solution flow rate was not critical. However, the difference in flow rates between the three tests must be emphasized. The PNNL disk test was completed at 6.35 bed volumes per minute (BV/min), whereas the flow rates for the cartridge tests were much higher. The PADU was run at 28.1 BV/min, while the $3 \mathrm{M}$ cartridge test was run at constant pressure $(10 \mathrm{psig})$ and the flow rate varied from 17.7 to $14.0 \mathrm{BV} / \mathrm{min}$. The effect of flow rate on ion exchange breakthrough curves is well known (Kurath et al. 1994) and may affect the results presented in this report.

\subsection{Ion Exchange Distribution}

Although batch distribution coefficients $\left(\mathrm{K}_{d} \mathrm{~s}\right)$ were not determined for the experiments described in this report, the information in this section is useful for understanding the relationship of the current disk and cartridge loading experiments to previous batch $\mathrm{K}_{\mathrm{d}}$ results. The column size is estimated by carefully analyzing these data.

The batch $\mathrm{K}_{\mathrm{d}}\left(\mathrm{K}_{\mathrm{d}}=[\mathrm{Cs}]_{\text {solid }} \div[\mathrm{Cs}]_{\text {liquid }}\right)$ is an equilibrium measure of the overall ability of the solid phase ion exchange material to remove an ion from solution under the particular experimental conditions 
Table 2.1. Comparison of Experimental Test Conditions for the PNNL Laboratory Disk Test, the $3 \mathrm{M}$ Laboratory Cartridge Test, and the N-Springs PADU Demonstration

\begin{tabular}{||l|c|c|c||}
\hline \multicolumn{1}{|c|}{ Parameter } & $\begin{array}{c}\text { PNNL Laboratory } \\
\text { Disk Test }\end{array}$ & $\begin{array}{c}\text { 3M Laboratory } \\
\text { Cartridge Test }\end{array}$ & $\begin{array}{c}\text { Actual Test } \\
\text { N-Springs }\end{array}$ \\
\hline \hline Analytical Method & GEA Sr-85 & ICP & ICP and Sr-90 \\
\hline Sorbent Material & NaTi & NaTi & NaTi \\
\hline Sorbent Mass $(\mathrm{g})$ & 0.593 & 100 & 300 \\
\hline Sorbent BV $(\mathrm{mL}, \mathrm{L})$ & $0.982 \mathrm{~mL}$ & $0.163 \mathrm{~L}$ & $0.488 \mathrm{~L}$ \\
\hline Sorbent Area $\left(\mathrm{cm}^{2}\right)$ & 4.91 & 680 & 2040 \\
\hline Number of Pleats & 0 & 13 & 39 \\
\hline Pleat Height $(\mathrm{cm})$ & 0 & 1.59 & 1.59 \\
\hline Pleat Length (cm) & 0 & 16.5 & 16.5 \\
\hline Sorbent Fraction & 0.72 & 0.72 & 0.72 \\
\hline Sorbent Particle $(\mu \mathrm{m})$ & 12.4 & 12.4 & 12.4 \\
\hline Sorbent Thickness $(\mathrm{cm})$ & 0.2 & 0.24 & 0.24 \\
\hline Solution Flow Rate $(\mathrm{mL} / \mathrm{min})$ & 6.24 & 2870 & 13,700 \\
\hline Solution Flow Rate $(\mathrm{BV} / \mathrm{min})$ & 6.35 & 17.7 & 28.1 \\
\hline Solution Flow Rate (cm/min) & 1.27 & 4.21 & 6.7 \\
\hline Sorbent Lot \# & $92095-2$ & $\mathrm{NA}$ & $\mathrm{NA}$ \\
\hline Flow Rate (L/min) & 0.00624 & $2.3-2.9$ & 13.7 \\
\hline Flow (mL min $\left.{ }^{-1} \mathrm{~g}^{-1}\right)$ & 10.5 & 28.7 & 45.7 \\
\hline (a) Sample information not available. & & & \\
\hline
\end{tabular}


Table 2.2. Analytical Results for the Composition of $3 \mathrm{M}$ Simulant and Actual N-Springs Water

\begin{tabular}{|c|c|c|c|}
\hline \multirow[b]{2}{*}{ Species } & \multicolumn{3}{|c|}{ 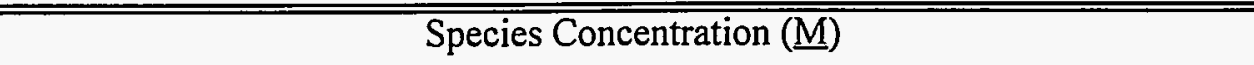 } \\
\hline & PNNL Lab Test $^{(\mathrm{a})}$ & 3M Simulant & $\mathrm{N}$-Springs Test $\mathrm{t}^{(\mathrm{b})}$ \\
\hline $\mathrm{Ba}$ & $1.15 \mathrm{E}-07$ & $0.00 \mathrm{E}+00$ & $(1.12 \pm 0.03) E-07 n=18$ \\
\hline $\mathrm{Ca}$ & $7.39 \mathrm{E}-04$ & $7.24 \mathrm{E}-04$ & $(7.28 \pm 0.07) E-04 n=19$ \\
\hline $\mathrm{K}$ & $5.29 \mathrm{E}-05$ & $5.12 \mathrm{E}-05$ & $(5.35 \pm N A) E-05 n=1$ \\
\hline $\mathrm{Mg}$ & $2.20 \mathrm{E}-04$ & $2.06 \mathrm{E}-04$ & $(2.16 \pm 0.02) E-04 n=19$ \\
\hline $\mathrm{Na}$ & $1.64 \mathrm{E}-04$ & $1.74 \mathrm{E}-04$ & $(2.61 \pm 0.13) E-04 n=19$ \\
\hline$P$ & $3.45 \mathrm{E}-06$ & $0.00 \mathrm{E}+00$ & $(3.39 \pm 0.18) E-06 n=5$ \\
\hline $\mathrm{S}$ & $2.30 \mathrm{E}-04$ & $2.29 \mathrm{E}-04$ & $\mathrm{NA}^{(\mathrm{c})}$ \\
\hline$\overline{\mathrm{Si}}$ & $3.33 \mathrm{E}-04$ & $0.00 \mathrm{E}+00$ & $(3.21 \pm 0.05) E-04 n=19$ \\
\hline $\mathrm{Sr}$ & $1.49 \mathrm{E}-06$ & $1.71 \mathrm{E}-06$ & $(1.49 \pm 0.02) E-06 n=19$ \\
\hline Sr-90. & $1.10 \mathrm{pCi} / \mathrm{mL}$ & $0.00 \mathrm{E}+00$ & $(1.35 \pm 0.10) \mathrm{pCi} / \mathrm{mL} \mathrm{n}=3$ \\
\hline $\mathrm{Ca} / \mathrm{Sr}$ Ratio & $4.98 E+02$ & $4.23 E+02$ & $(4.88 \pm 0.08) E+02 n=19$ \\
\hline \multicolumn{4}{|c|}{$\begin{array}{l}\text { (a) Sample collected from the N-Springs well 199-N-106A by AG Rizzo on 11/1/95 at 11:10 a.m. } \\
\text { (b) Sample collected from the N-Spring Pump and Treat Demonstration Facility by DL Bowers } \\
\text { on 11/25/96 at 10:30 a.m. } \\
\text { (c) Not analyzed. }\end{array}$} \\
\hline
\end{tabular}

that exist during the contact. In most batch $\mathrm{K}_{\mathrm{d}}$ tests, a known quantity of ion exchange material is placed in contact with a known volume of solution containing the ions of interest (in this case, strontium). The material is allowed to contact the solution for a sufficient time to achieve equilibrium at a constant temperature, after which the solid ion exchange material and liquid supernate are separated and analyzed. The equation for determining the $K_{d}$ can be simplified by determining the concentration of the analyte before and after contact, and calculating the quantity of analyte on the ion exchanger by difference (Equation 1).

$$
K_{d}=\frac{\left(C_{i}-C_{f}\right)}{C_{f}} \times \frac{V}{M * F}
$$

where $C_{i}=$ the initial amount or activity of the ion of interest in the feed solution prior to contact

$\mathrm{C}_{\mathrm{f}}=$ the amount or activity after contact

$\mathrm{V}=$ the solution volume

$M$ = the exchanger mass

$F$ = the mass of dry ion exchanger divided by the mass of wet ion exchanger (F-factor). 
$\mathrm{K}_{\mathrm{d}}(\mathrm{mL} / \mathrm{g})$ represents the theoretical volume of solution that can be processed per mass of exchanger under equilibrium conditions. Lambda, the theoretical number of bed volumes of solution that can be processed per volume of exchanger, is obtained by multiplying $K_{d}$ by the exchanger bed density, $\rho_{b}(g / m L)$, as shown in Equation 2. Lambda is termed the column distribution ratio and is useful for estimating the $0.5 \mathrm{C} / \mathrm{C}_{0}$ point in column loading experiments. Historically, several methods and materials, NaTi included, have been employed to remove radioactive strontium from waste matrices (Brown et al. 1994).

$$
\lambda=K_{\mathrm{d}} \times \rho_{\mathrm{b}}
$$

\subsection{Preliminary Disk Tests}

The ion exchange material used in the preliminary PNNL laboratory tests consisted of a fine powdered sodium nonatitanate (NaTi) (AlliedSignal, Des Plaines, IL) entrapped in a proprietary web matrix developed by $3 \mathrm{M}$ (St. Paul, MN). The material (3M Lot \#92095-2) was cut into a $2.5-\mathrm{cm}$-dia. disk $(0.2 \mathrm{~cm}$ thick) with a leather punch and placed into a Millipore in-line disk filter holder, as shown in Figure 2.1. The ion exchange web was used in the form received from the manufacturer and was not chemically pretreated. The feed solution (N-Springs water from well 199-N-106A) was passed upwards through the web at $6.24 \mathrm{~mL} / \mathrm{min}(6.35 \mathrm{BV} / \mathrm{min})$ and ambient temperature $\left(25^{\circ} \mathrm{C}\right)$. The system pressure was measured upstream of the web and the effluent downstream was discharged to either a sample or waste container at atmospheric pressure. After loading, the strontium was removed from the material by eluting with $0.5 \mathrm{M}$ $\mathrm{HNO}_{3}$ at $6.08 \mathrm{~mL} / \mathrm{min}(6.19 \mathrm{BV} / \mathrm{min})$ and ambient temperature $\left(25^{\circ} \mathrm{C}\right)$. Following elution and in preparation for a second loading cycle, the web was flushed with distilled water, $50-\mathrm{mL} 2 \mathrm{M} \mathrm{NaOH}$, and a second distilled water rinse until the effluent reached $\mathrm{pH}$ 8. The system was then left overnight and the second load/elute cycle was initiated the following morning. All data described in this

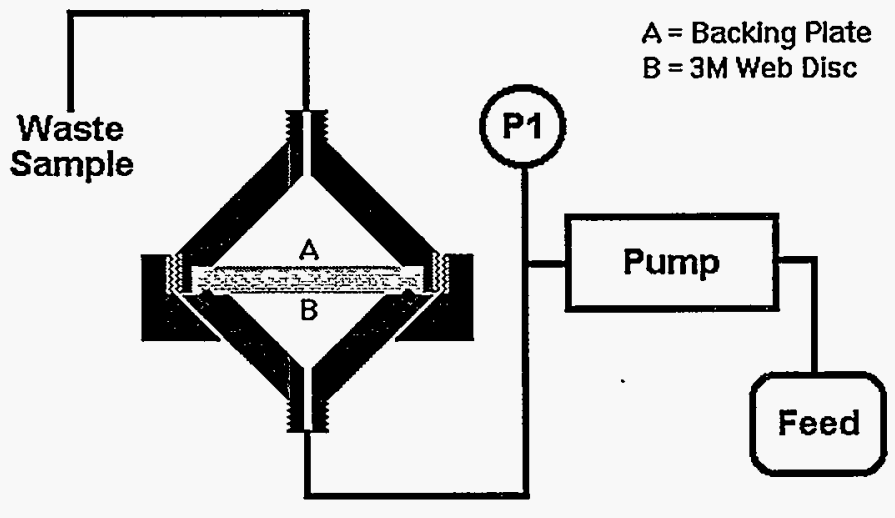

Figure 2.1. Schematic Diagram of the Laboratory Disk Filtration Apparatus 
report are from the second cycle. Elution and/or repeated cycling of the disk was not necessary for the current systems evaluation and for determining loading predictions at the Hanford N-Springs, but was completed for future reference in case elution is necessary for additional applications of this technology.

\subsection{Preliminary Cartridge Tests}

The preliminary cartridge test was done to evaluate the strontium loading required to produce a full breakthrough curve for an 18 -cm-long NaTi cartridge before using the PADU skid unit to process $\mathrm{N}$-Springs water. $3 \mathrm{M}$ personnel tested a single $\mathrm{NaTi}$ cartridge for the $\mathrm{Sr}$ loading characteristics before the entire lot of cartridges was delivered for the N-Springs PADU field demonstration. The NaTi material was converted to the sodium form by pretreating the intact cartridge with a solution containing $0.1 \mathrm{M} \mathrm{NaOH}$ and $5 \mathrm{M} \mathrm{NaNO}_{3}$, followed by rinsing with deionized water. The $18-\mathrm{cm}$ cartridge (Figure 2.2) was installed in a commercial filtration housing, and a simulated ground water designed to mimic the actual $\mathrm{N}$-Springs water was passed through the system at constant pressure and at a flow rate that varied from 2.88 to $2.27 \mathrm{~L} / \mathrm{min}$. Table 2.2 provides the exact composition of the ground-water simulant. The solution flowed inward (radially) through the web material and out the top of the cartridge in the axial direction, as shown in Figure 2.2. The flow rate varied between 17.7 and $14.0 \mathrm{BV} / \mathrm{min}$.

Throughout the test, a constant pressure drop of approximately 10 to 12 psig was maintained across the cartridge material. Temperature control during cartridge loading was not attempted but ambient was $25^{\circ} \mathrm{C}$. Table 2.1 lists additional experimental conditions. Elution and/or repeated cycling of the cartridge during the field demonstration was not planned and therefore was not necessary for evaluating the overall system.

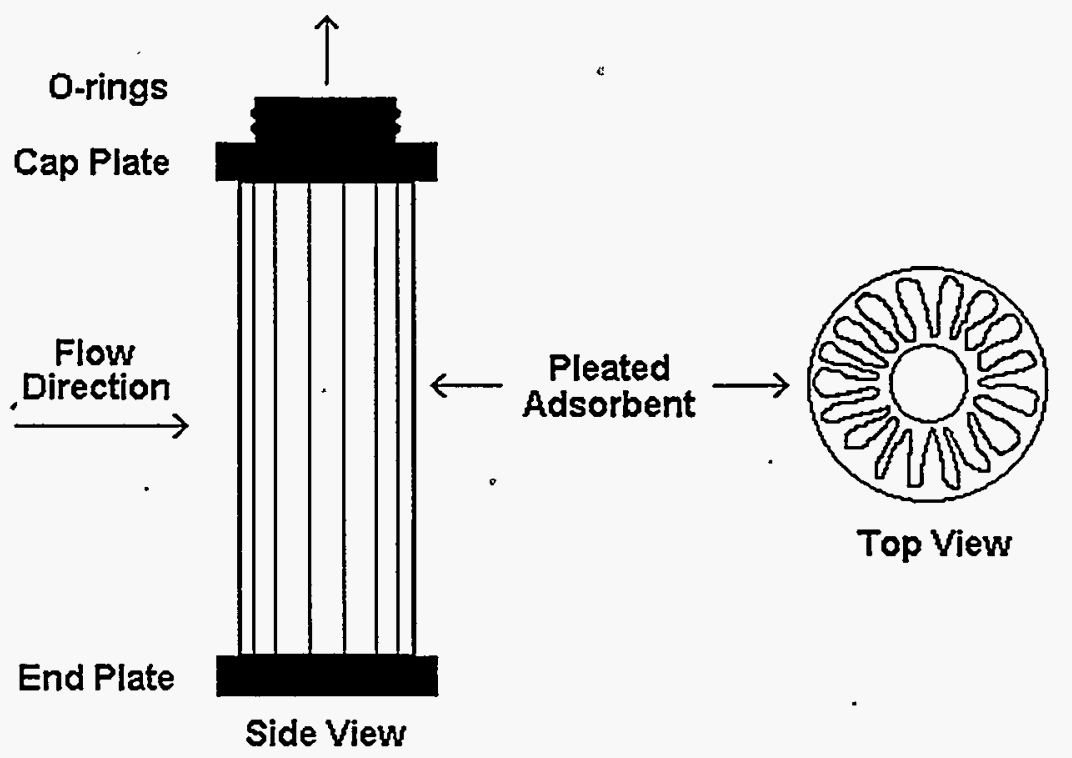

Figure 2.2. Schematic Diagram of the $3 \mathrm{M}$ Cartridge 


\subsection{N-Springs PADU Test}

The PADU is a skid-mounted, cartridge-based system designed to demonstrate the removal of various radionuclides from contaminated ground water or other low-level process streams. The selfcontained system is approximately $4 \times 5 \times 4$ feet and consists of three vessels, each of which contain multiple cartridges in parallel. Figure 2.3 shows a schematic diagram of the PADU system, with a photograph of the unit in operation at the N-Springs Pump and Treat Demonstration Facility shown in Figure 2.4.

Section 2.4 described the cartridges included in the PADU. The cartridge size and number can vary, but for this demonstration, three 18-cm cartridges per vessel were used. Two-stage pre-filtration capability (in the current experiment, $2-\mu \mathrm{m}(3 \mathrm{M})$ and $0.1-\mu \mathrm{m}$ (Pall) commercial filters), pressure indicators, electronic valves, and all associated piping are included with the system. In addition, the unit is electronically controlled and can shut down automatically if over-pressure conditions occur.

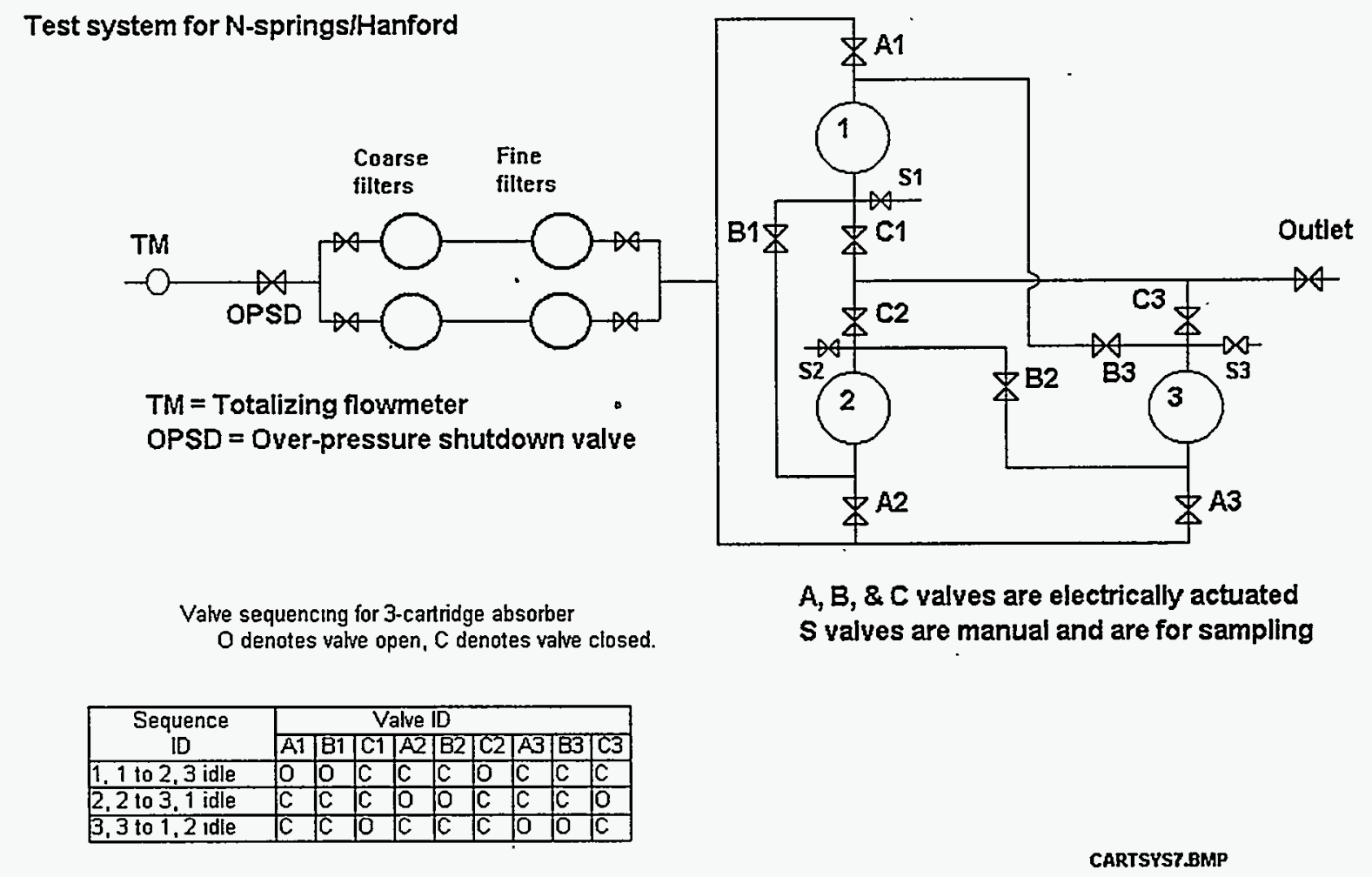

Figure 2.3. Schematic Diagram of the 3M PADU 


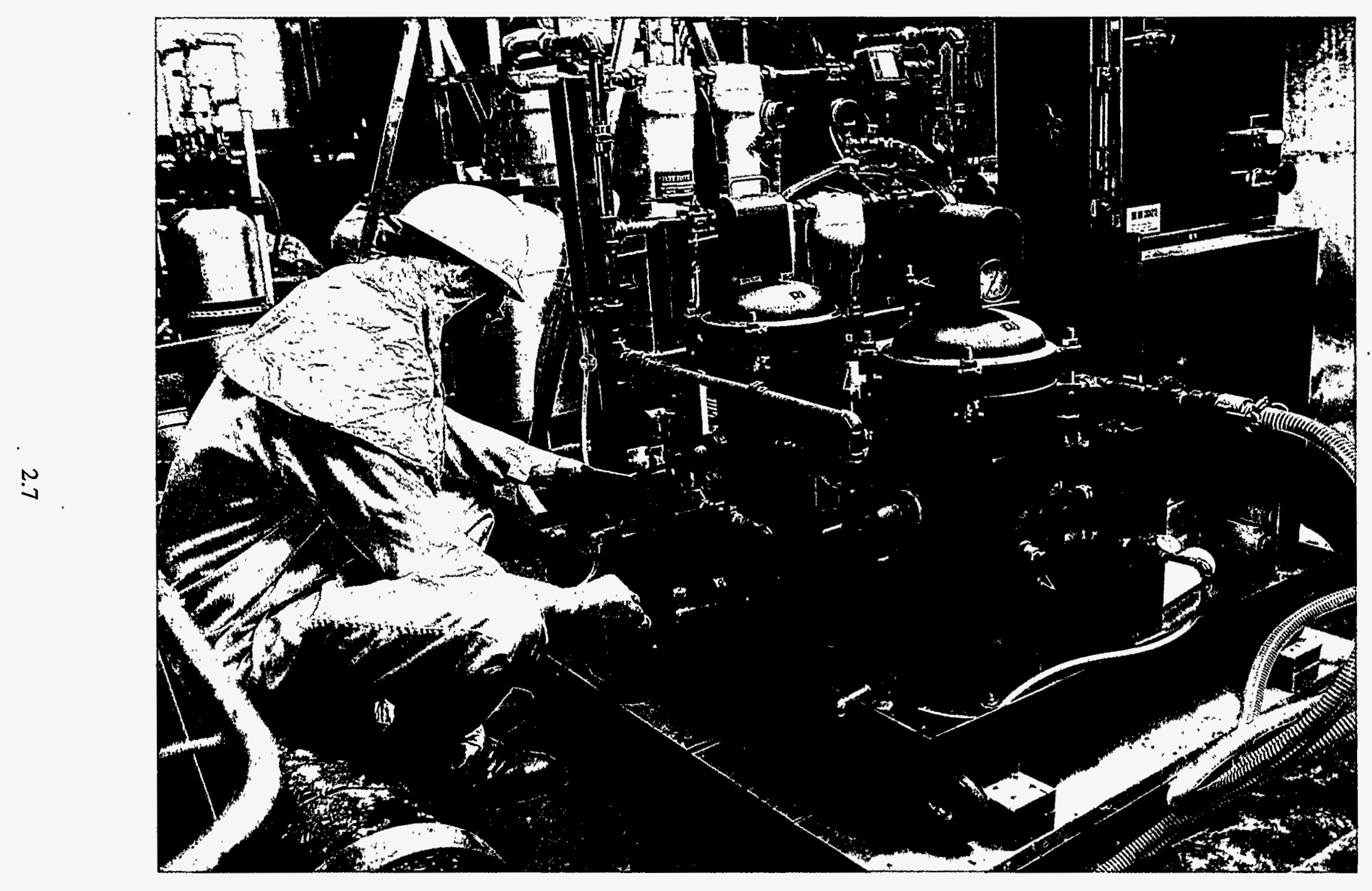

Figure 2.4. 3M PADU Used at Hanford N-Springs 
During normal operations, solution flows through two vessels in series, with the third vessel held offline in reserve. The system automatically switches the sequence of vessels based on a pre-programmed cycle time. In the first sequence, the first or leading vessel (\#1) is completely loaded with the radionuclide of interest, while the second or trailing vessel (\#2) polishes the remaining radionuclide from the system effluent. In the second sequence, flow is electronically switched so vessel \#2 becomes the leading vessel and vessel \#3 is placed in service as the trailing or polishing vessel. At this point, vessel $\# 1$ is taken off-line and the loaded cartridges are manually removed for disposal. It is important to note that the system is designed as a demonstration unit for low-activity solutions and requires contact maintenance (e.g., cartridge removal by hand). The use of this system for highly radioactive solutions was not intended and is not recommended.

The PADU system was operated at ambient temperature and used a side stream from the N-Springs Pump and Treat Demonstration Facility. Because the demonstration took place in January and involved water from the 199-N-106A well, the water temperature was substantially lower than it was in the previously described laboratory tests (see Sections 2.3 and 2.4). The system flow rate was approximately $13.6 \mathrm{~L} / \mathrm{min}$ or $28.1 \mathrm{BV} / \mathrm{min}$, much faster than the flow rate used in the previous laboratory tests (see Table 2.1). The effect of temperature and flow rate on ion exchange breakthrough curves has been investigated previously (Kurath et al. 1994) and may affect the results presented in this report. In general, earlier breakthrough is observed at higher flow rates. 


\subsection{Results and Discussion}

\subsection{Strontium Loading Comparison}

Figure 3.1 shows results for the removal of strontium from simulated and actual N-Springs water. The normalized strontium concentration $\left(\mathrm{Sr} C / \mathrm{C}_{0}\right)$ is plotted against the $\mathrm{BVs}$ of solution passed through the NaTi web. For visual clarity, the data are plotted in the log-probability format. The typical sigmoidal or S-shaped loading breakthrough curve will appear linear when displayed in this manner (Buckingham 1967). The data are displayed in this format to facilitate comparison between the smallscale disk tests, the larger-scale cartridge tests, and the variety of analytical methods used to measure strontium concentration. For reference, Table 2.2 displays the initial concentration (approximately $1.5 \mathrm{E}-06 \mathrm{M} \mathrm{Sr}$ ) of strontium in the various feed solutions.

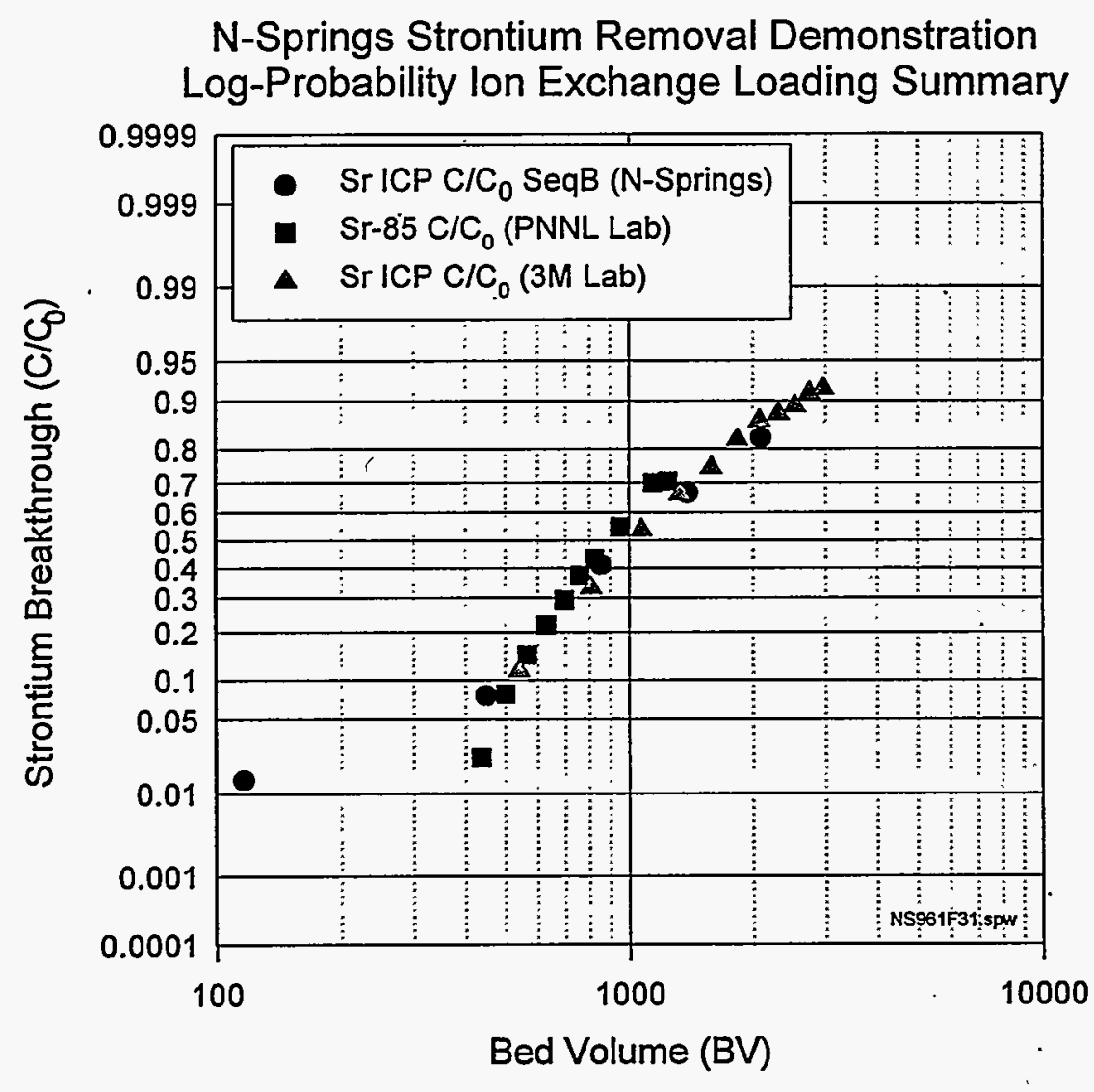

Figure 3.1. Comparison of Strontium Breakthrough Curves for NaTi/WWL Disks and Cartridges in Simulated and Actual Ground Water from Hanford N-Springs 
As shown in Figure 3.1, the $0.5 \mathrm{C} / \mathrm{C}_{0}$ breakthrough point corresponds to approximately 900,1000 , and $1000 \mathrm{BV}$ of solution passed through the NaTi web for the PNNL disk test, the $3 \mathrm{M}$ cartridge simulant test, and the PADU N-Springs demonstration, respectively. As described in Section 2.2 , the $0.5 \mathrm{C} / \mathrm{C}_{0}$ point can be used as an estimate of the theoretical volume of solution that can be processed to fully load an ion exchanger. The assumption is valid if the wave shape of the loading curve is symmetric about the $0.5 \mathrm{C} / \mathrm{C}_{0}$ point. At this point, one can assume that the quantity of radionuclide that has exited the column (e.g., broken through) is equivalent to the quantity that can still be loaded if the experiment were continued to $1.0 \mathrm{C} / \mathrm{C}_{0}$. Alternatively, one can integrate the amount of strontium exiting the disk or cartridge from the analytical data and back calculate the strontium loading.

From the data in Figure 3.1, it appears that an accurate estimate of the PADU operations was obtained using either a small-scale disk, single cartridge, or a ground-water simulant with the approriate chemical composition. It is interesting to note that the results were not affected by the higher strontium concentration of the $3 \mathrm{M}$ simulant $(1.71 \mathrm{E}-06 \underline{\mathrm{M}})$ as compared to the actual N-Springs water $(1.49 \mathrm{E}-06 \mathrm{M})$. It is likely that the calcium concentration, which is nearly 500 times higher than the strontium concentration, is controlling the volume of solution that can be processed.

\subsection{Interferant Loading}

Figure 3.2 shows the $3 \mathrm{M}$ cartridge results for the removal of calcium, magnesium, and strontium from the simulated N-Springs solution. Magnesium is initially loaded on the NaTi material for the first $500 \mathrm{BV}$, but is displaced later in the loading sequence. The magnesium concentration exceeds the input value between 500 and $1500 \mathrm{BV}$, indicating that the magnesium is being eluted from the cartridge by another more strongly bound ion (e.g., calcium and/or strontium). Calcium, however, is not displaced and is loaded on the NaTi in a manner similar to strontium. This same alkaline earth breakthrough behavior was noted previously (Herbst et al. 1995) for the NaTi material loaded with ground water from the Test Area North (TAN) at the Idaho National Engineering Laboratory (INEL). Since the concentration of calcium is approximately 500 times greater than that of strontium, the NaTi becomes saturated with calcium. Therefore, the majority of the material's capacity is filled with calcium. Strontium breakthrough is eventually observed even though the material exhibits a high selectivity for strontium over calcium. It is interesting to note that the cartridge effluent strontium concentration does not completely return to the influent or feed value over the course of the experiment, suggesting that either strontium continues to load onto the NaTi material and additional solution could be processed given additional time, or the influent sample analysis $\left(\mathrm{C}_{0}\right)$ may be in error.

\subsection{PADU Demonstration}

Figures 3.3 and 3.4 show the results for the PADU demonstration. The PADU was evaluated through three load sequences, each containing two vessels in series and one cartridge change-out. Unfortunately, an ongoing operational failure prevented the system from loading two vessels in series. One or more of the cartridges in vessel $\# 2$ detached during system pressurization before the experiment began. Because of this problem, the cartridges never properly loaded and they allowed unprocessed 
N-Springs Strontium Removal Demonstration

$\mathrm{Ca}, \mathrm{Mg}$, Sr lon Exchange Loading Summary

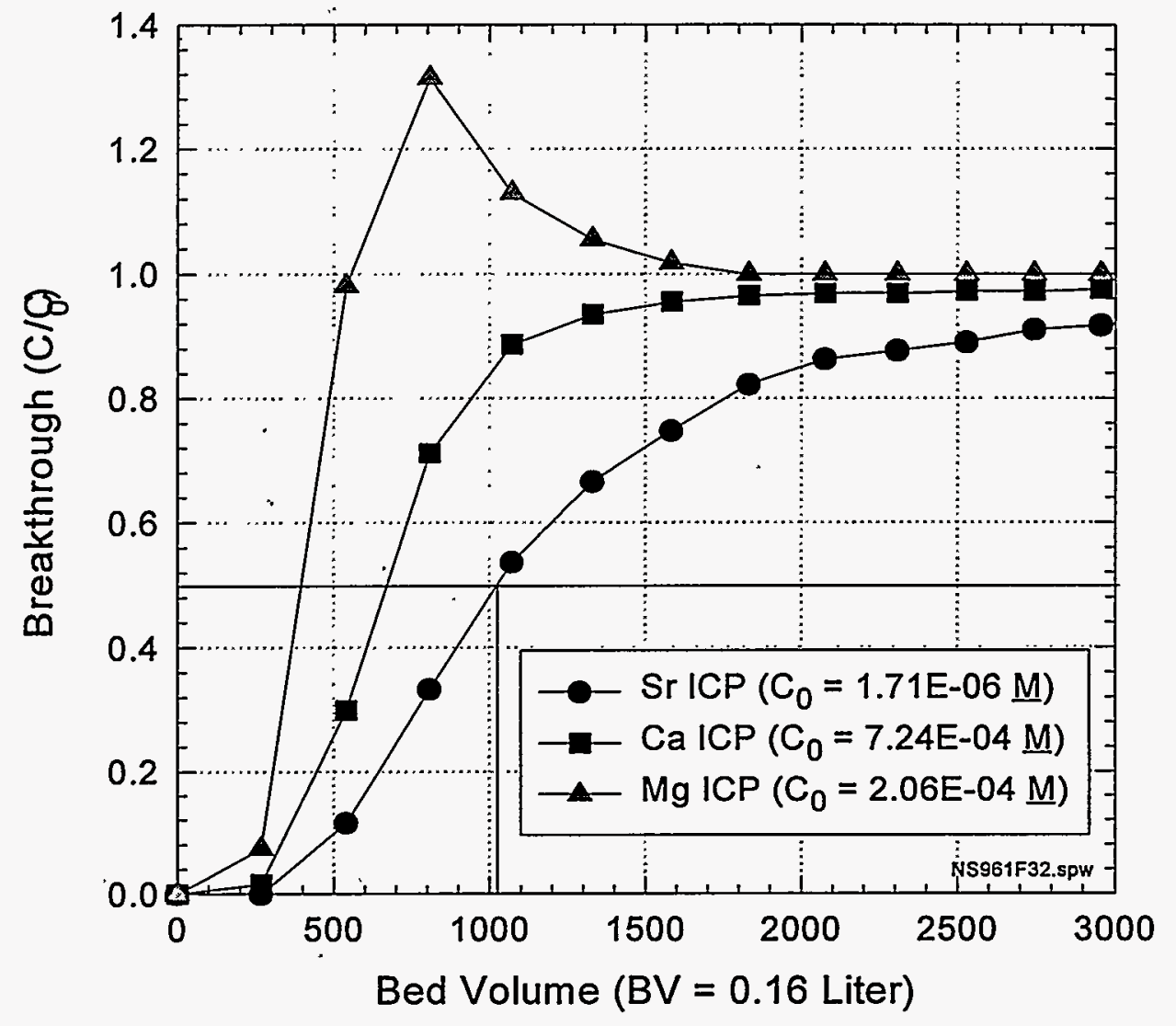

Figure 3.2. Calcium, Magnesium, and Strontium Breakthrough Curves for a Laboratory-Scale NaTi/WWL Cartridge in Simulated Ground Water from Hanford N-Springs

water to pass through the vessel throughout the entire test. When the unit electronically switched to the second sequence, this vessel became the lead vessel. At this point, solution passed untreated to the trailing vessel, forcing a premature loading of those cartridges. In effect, at no point during the experiment were there two fully functional vessels in series.

The PADU system was designed to hold $25-\mathrm{cm}$ cartridges, not the $18-\mathrm{cm}$ cartridges. Because of the time constraints placed on the demonstration, $3 \mathrm{M}$ could not produce the larger cartridges on such short notice. In addition, a spacer capable of holding the smaller cartridges in place was thought to be unnecessary and potentially difficult to work with under radiological conditions. For these reasons, the system was delivered without the necessary spacers. During the preliminary system pressurization and functional testing, a large back pressure developed that evidently dislodged the cartridges from their position within the second vessel. The pressure drop across each vessel indicated a problem might exist, but the specific problem and its source could not be confirmed until the test had been completed. 
N-Springs Strontium Removal Demonstration

$\mathrm{Ca}, \mathrm{Mg}$, Sr lon Exchange Loading Summary

3M PADU Samples NSS3-C0 to NSS3-C4

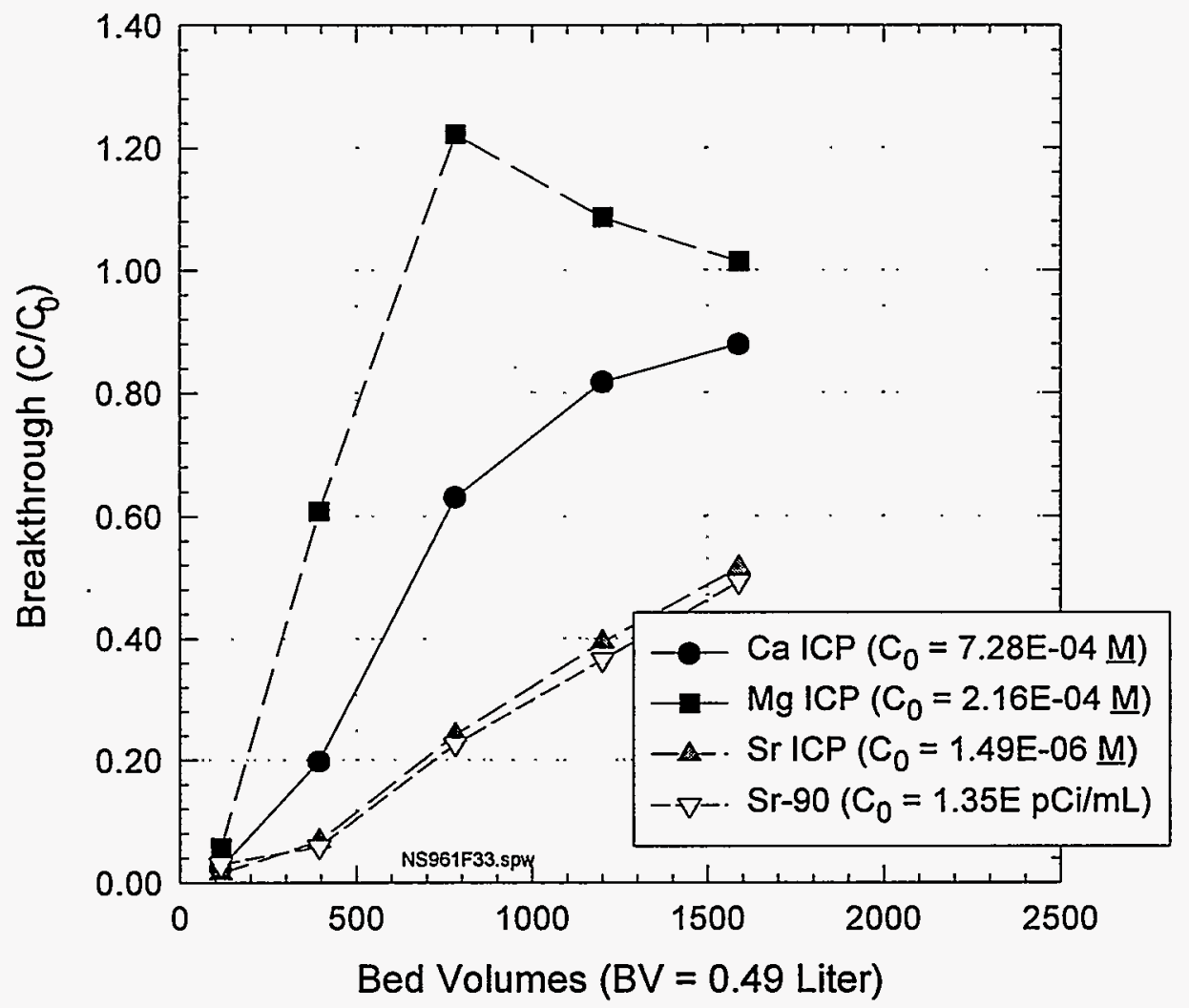

Figure 3.3. Calcium, Magnesium, and Strontium Breakthrough Curves for a $\mathrm{NaTi} / W W L$ Cartridge in Actual Ground Water During the Third Sequence of Hanford N-Springs PADU Demonstration

The results displayed in Figure 3.3 depict the loading of calcium, magnesium, and strontium on the three parallel cartridges contained in the trailing vessel (\#1) during the third PADU sequence. Strontium removal data were collected using strontium ICP and strontium-90 beta counting. Note that the two strontium analyses are nearly identical, with the strontium- 90 beta counting results only slightly below those of the strontium ICP. One possible reason for this difference could be a less than $100 \%$ collection efficiency during the strontium-90 analytical separation method. Note that the strontium breakthrough results displayed in Figure 3.3 are slightly better (i.e., shifted to higher volume) than those shown in Figure 3.1 because of a slightly reduced strontium concentration ( $1.0 \mathrm{vs.} 1.3 \mathrm{pCi} / \mathrm{mL})$ reaching the trailing vessel.

The effect of the dislodged cartridge is evident in Figure 3.4. During the first sequence, the effluent from both vessel \#1 and \#2 show identical breakthrough, suggesting that the second vessel is ineffective. During the second sequence, vessel \#2 passes untreated water (constant $\mathrm{C} / \mathrm{C}_{0}=1$ ) to the third vessel, 


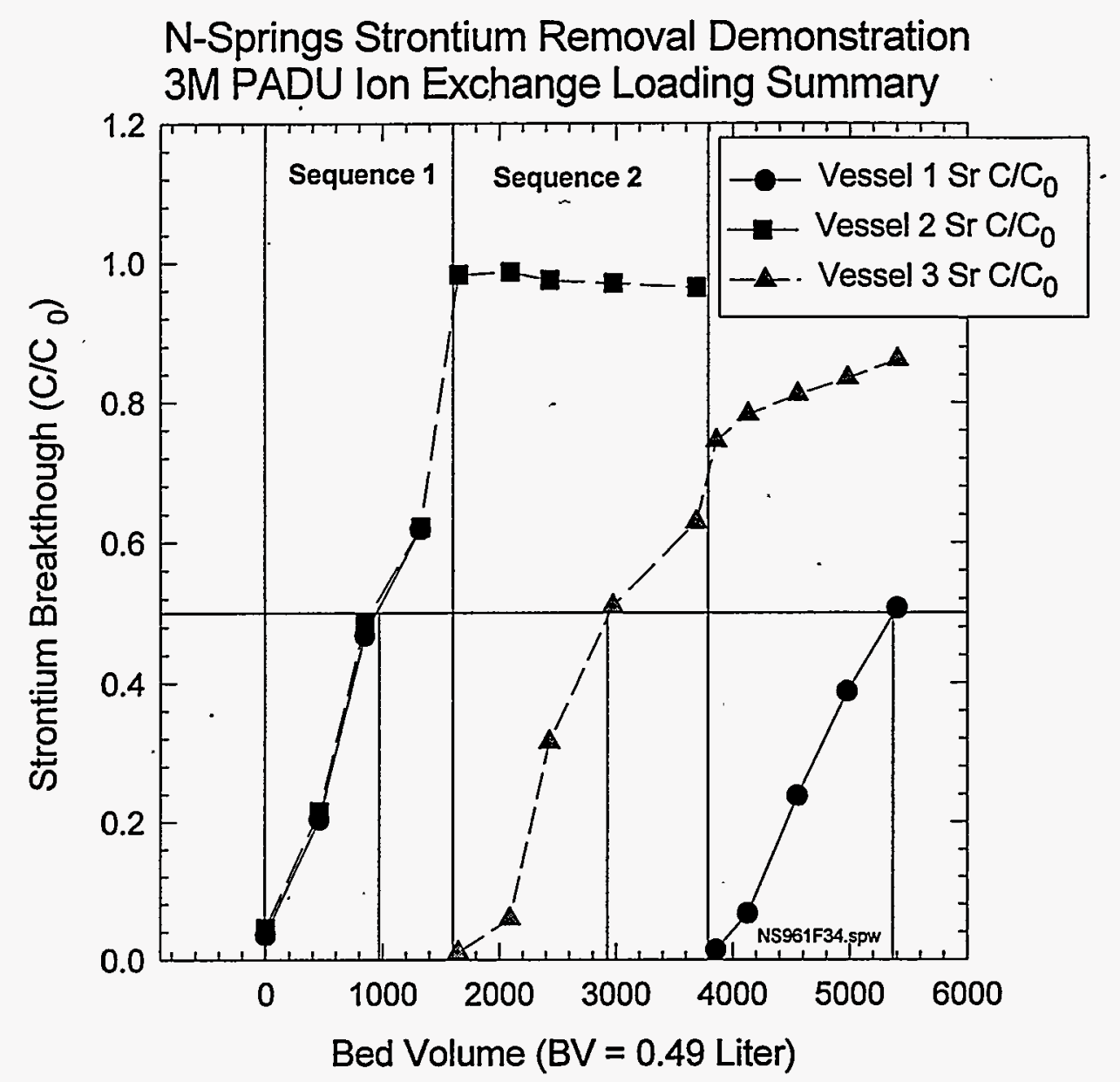

Figure 3.4. Strontium Breakthrough Curves During PADU Sequencing at Hanford N-Springs

which loads to nearly $0.7 \mathrm{C} / \mathrm{C}_{0}$. At this point, the unit switched to the third sequence and the effluent of vessel \#3 increased to nearly $0.9 \mathrm{C} / \mathrm{C}_{0}$. A slightly delayed breakthrough curve is observed for vessel \#1 since that vessel is in the trailing position and is subjected to a slightly reduced strontium concentration.

\subsection{Ion Exchange Loading Capacity}

The total cation loading of the $\mathrm{NaTi} / \mathrm{WWL}$ web material was evaluated by determining the influent and effluent barium, calcium, magnesium, and strontium concentrations as a function of time and volume over the course of the PADU field demonstration at the Hanford N-Springs. The elemental loadings are displayed in Table 3.1 as a function of NaTi/WWL web mass $(\mathrm{mmol} / \mathrm{g})$ and volume $(\mathrm{mmol} / \mathrm{mL})$. From these data, it is clear that the majority of the NaTi/WWL web capacity $(9.47 \mathrm{E}-01 \mathrm{mmol} / \mathrm{g})$ is loaded with calcium (8.68E-01 mmol/g) under the conditions of the test. Based on an assumed total capacity of $9.47 \mathrm{E}-01 \mathrm{mmol} / \mathrm{g}$, only $0.30 \%$ of the material's capacity is loaded with strontium. Barium, calcium, and magnesium occupy $0.03 \%, 91.66 \%$, and $8.01 \%$ of the total, respectively. 
The capacity and loading data described above assume that the NaTi/WWL material removes only the detected alkaline earth metals (i.e., barium, calcium, magnesium, and strontium) from the N-Springs water. No other metals loading was measured using the ICP analytical data because the data were below the detection limit. However, the sodium ICP data displayed in Table 3.1 provide an additional check on the NaTi/WWL capacity. To preserve the ionic charge balance, for each divalent (e.g., $\mathrm{Ca}^{2+}$ ) cation loaded, two monovalent (in this case, $\mathrm{Na}^{+}$) cations must be expelled from the material. During the PADU demonstration, $1.78 \mathrm{E}+00 \mathrm{mmol} \mathrm{Na}$ was released per gram of NaTi/WWL. In comparison, a total of $9.47 \mathrm{E}-01 \mathrm{mmol}(1.89 \mathrm{E}+00 \mathrm{meq})$ of divalent cations were loaded. These data provide a secondary check and indicate that the majority of the ion exchange has been taken into account. However, it is important to note that these data are reported on the basis of the entire NaTi/WWL web mass or volume and not the mass or volume of the NaTi material alone.

Using the data from Table 3.1 and the equilibrium concentration of barium, calcium, magnesium, and strontium in the actual N-Springs water (Table 2.2), the ion exchange selectivity coefficient $\left(\mathrm{K}_{c}\right)$ can be calculated from the following equation:

$$
K_{c}=\frac{C_{B}^{v_{A}} \times C_{S A}^{v_{B}}}{C_{A}^{v_{B}} \times C_{S B}^{v_{A}}}
$$

where $C_{A}$ and $C_{B}=$ the equilibrium concentrations of ions $A$ and $B$ in solution

$\mathrm{C}_{\mathrm{SA}}$ and $\mathrm{C}_{\mathrm{SB}}=$ the equilibrium concentrations of ions $\mathrm{A}$ and $\mathrm{B}$ on the ion exchange material

$\mathrm{V}_{\mathrm{A}}$ and $\mathrm{V}_{\mathrm{B}}=$ the ion valences of each ion, respectively.

$\mathrm{K}_{\mathrm{c}}$ is a measure of the preference of an ion exchange material for one ionic species (A) over another (B) and accounts for the concentrations of each ion in solution. In the actual N-Springs water, the calculated selectivity of strontium over barium, calcium, and magnesium is $0.569,2.57$, and 29.7 , respectively.

Table 3.1. Alkaline Metal Loading of the PADU NaTi/WWL Web with Actual N-Springs Water

\begin{tabular}{|c|c|c|c||}
\hline \multirow{2}{*}{ Species } & \multicolumn{3}{|c|}{ Elemental Loading of NaTi/WWL Web } \\
\cline { 2 - 4 } & $\mathrm{mmol} / \mathrm{g}$ & $\mathrm{mmol} / \mathrm{mL}$ & Capacity (\%) \\
\hline \hline $\mathrm{Ba}$ & $2.84 \mathrm{E}-04$ & $1.75 \mathrm{E}-04$ & $0.03 \%$ \\
\hline $\mathrm{Ca}$ & $8.68 \mathrm{E}-01$ & $5.34 \mathrm{E}-01$ & $91.66 \%$ \\
\hline $\mathrm{Mg}$ & $7.58 \mathrm{E}-02$ & $4.67 \mathrm{E}-02$ & $8.01 \%$ \\
\hline $\mathrm{Sr}$ & $2.85 \mathrm{E}-03$ & $1.75 \mathrm{E}-03$ & $0.30 \%$ \\
\hline Total (mmol) & $9.47 \mathrm{E}-01$ & $5.83 \mathrm{E}-01$ & $100.00 \%$ \\
\hline Total (meq) & $1.89 \mathrm{E}+00$ & $1.17 \mathrm{E}+00$ & $100.00 \%$ \\
\hline $\mathrm{Na}$ & $-1.78 \mathrm{E}+00$ & $-1.10 \mathrm{E}+00$ & $-94.25 \%$ \\
\hline Balance (meq) & $1.09 \mathrm{E}-01$ & $6.70 \mathrm{E}-02$ & $-11.51 \%$ \\
\hline
\end{tabular}




\subsection{Conclusions}

Strontium removal from simulated and actual N-Springs well water was demonstrated using an AlliedSignal NaTi material engineered into a web adsorbent cartridge (NaTi/WWL) developed by $3 \mathrm{M}$. Laboratory tests were completed using a $2.5-\mathrm{cm}$ disk and an $18-\mathrm{cm}$ cartridge. The laboratory tests effectively predicted the loading breakthrough curve expected for the multiple cartridge/multiple vessel PADU. In every test, approximately $1000 \mathrm{BV}$ of solution was passed through the NaTi material before reaching $0.5 \mathrm{C} / \mathrm{C}_{0}$. This was the case irrespective of solution (simulated or actual), material geometry (disks or cartridges), or material volume (single or multiple cartridges). The NaTi material was shown to remove calcium, magnesium, and strontium from the $\mathrm{N}$-Springs ground-water matrix. Based on these experiments, the following observations and conclusions are made:

- The 3M PADU was operated successfully by BHI personnel at the N-Springs Pump and Treat Demonstration Facility. Although minor system difficulties were encountered, the effectiveness of the NaTi/WWL membrane for removing strontium from Hanford ground water was demonstrated.

- Laboratory testing of small-scale disks and process-scale cartridges using simulated and actual ground water effectively predicted the field performance of the PADU. Approximately $1000 \mathrm{BVs}$ of solution could be processed before reaching a strontium $C / C_{0}$ of 0.5 . These data suggest that accurate scaleup of process performance data from laboratory disk tests to full-scale cartridge systems is likely. Complete loading breakthrough curves were generated for barium, calcium, magnesium, and strontium.

- The disk loading (mmol strontium per gram or milliliter of resin) of the NaTi/WWL material was calculated to be $2.61 \mathrm{E}-03 \mathrm{mmol} / \mathrm{g}(1.57 \mathrm{E}-03 \mathrm{mmol} / \mathrm{mL})$ for the actual N-Springs water. Elution was accomplished with $0.5 \mathrm{M} \mathrm{HNO}_{3}$ at $7.5 \mathrm{BV} / \mathrm{min}$ and required $80 \mathrm{BV}$ to reach 0.1 strontium $\mathrm{C} / \mathrm{C}_{0}$.

- During the field demonstration, the PADU cartridge loading ( $\mathrm{mmol} / \mathrm{g}$ ) was determined to be 2.84E-04, 8.68E-01, 7.58E-02, and 2.85E-03 for barium, calcium, magnesium, and strontium, respectively. In addition, $1.78 \mathrm{E}+00 \mathrm{mmol} \mathrm{Na} / \mathrm{g}$ was released during loading, confirming the mass balance.

Additional testing is needed to evaluate this material over a wider range of solution conditions and to compare its performance to other potential strontium removal candidates. 


\subsection{References}

Bray, L. A., L. K. Holton, T. R. Meyers, G. M. Richardson, and B. M. Wise. 1984. Experimental Data Developed to Support the Selection of a Treatment Process for West Valley Alkaline Supernatant. PNL-4969, Pacific Northwest Laboratory, Richland, Washington.

Bray, L. A., K. J. Carson, and R. J. Elovich. 1990. Cesium Recovery Using Savannah River Laboratory Resorcinol-Formaldehyde Ion Exchange Resin. PNL-7273, Pacific Northwest Laboratory, Richland, Washington.

Bray, L. A., K. J. Carson, and R. J. Elovich. 1993. Initial Evaluation of Sandia National Laboratory Prepared Crystalline Silico-Titanates for the Recovery of Cesium. PNL-8847, Pacific Northwest Laboratory, Richland, Washington.

Brown, G. N., L. A. Bray, C. D. Carlson, K. J. Carson, J. R. DesChane, R, J. Elovich, and P. K. Tanaka. 1994. Initial Evaluation of Processes Capable of Removing Strontium from Complexant-Containing Alkaline Waste Supernate. FY 1994 Final Report. TWRSPP-94-097, Pacific Northwest Laboratory, Richland, Washington.

Brown, G. N., S. R. Adami, L. A. Bray, S. A. Bryan, C. D. Carlson, K. J. Carson, J. R. DesChane, R. J. Elovich, S. J. Forbes, J. A. Franz, J. C. Linehan, W. J. Shaw, P. K. Tanaka, and M. R. Telander. 1995a. Chemical and Radiation Stability of SuperLig ${ }^{\circledR}$ 644, Resorcinol-Formaldehyde, and CS-100 Cesium Ion Exchange Materials. PNL-10772, Pacific Northwest National Laboratory, Richland, Washington.

Brown, G. N., J. R. Bontha, C. D. Carlson, K. J. Carson, J. R. DesChane, R. J. Elovich, D. E. Kurath, P. K. Tanaka, D. W. Edmonson, D. L. Herting, and J. R. Smith. 1995b. Ion Exchange Removal of Cesium from Simulated and Actual Supernate from Hanford Tanks 241-SY-101 and 241-SY-103. PNL-10792, Pacific Northwest National Laboratory, Richland, Washington.

Brown, G. N., L. A. Bray, and R. J. Elovich. 1995c. Evaluation and Comparison of SuperLig® 644, Resorcinol-Formaldehyde and CS-100 Ion Exchange Materials for the Removal of Cesium from Simulated Alkaline Supernate. PNL-10486, Pacific Northwest Laboratory, Richland, Washington.

Brown, G. N., L. A. Bray, C. D. Carlson, K. J. Carson, J. R. DesChane, R. J. Elovich, F. V. Hoopes, D. E. Kurath, L. L. Nenninger, and P. K. Tanaka. 1996. Comparison of Organic and Inorganic Ion Exchangers for Removal of Cesium and Strontium from Simulated and Actual Hanford 241-AW-101 DSSF Tank Waste. PNL-10920, Pacific Northwest National Laboratory, Richland, Washington. 
Buckingham, J. S. 1967. Waste Management Technical Manual. ISO-100 DEL, Hanford Atomic Products Operation, Richland, Washington.

Dirkes, R. L. 1990. 1988 Hanford Riverbank Springs Characterization Report. PNL-7500, Pacific Northwest Laboratory, Richland, Washington.

Hartman, M. J. and K. A. Lindsey. 1993. Hydrogeology of the 100-N Area, Hanford Site, Washington. WHC-SD-EN-EV-027, Westinghouse Hanford Company, Richland, Washington.

Herbst, R. S., K. N. Brewer, T. A. Todd, T. M. Kafka, L. R. White, and L. A. Bray. 1995. Decontamination of TAN Injection Well Water Using 3M Web Technology. INEL-95/0589, Lockheed Idaho Technologies Company, Idaho Falls, Idaho.

Kurath, D. E., L. A. Bray, K. P. Brooks, G. N. Brown, S. A. Bryan, C. D. Carlson, K. J. Carson, J. R. DesChane, R. J. Elovich, and A. Y. Kim. 1994. Experimental Data and Analysis to Support the Design of an Ion Exchange Process for the Treatment of Hanford Tank Waste Supernatant Liquids. PNL-10187, Pacific Northwest Laboratory, Richland, Washington. 
Appendix

Laboratory Data 
Table A.1: ICP-AES Instrument Characteristics and Performance

\begin{tabular}{|c|c|c|c|c|}
\hline Element & $\begin{array}{c}\text { Wavelength } \\
(\mathrm{nm})\end{array}$ & $\begin{array}{l}\text { Estimated } \\
\text { IDL (ppm) }\end{array}$ & $\begin{array}{c}\begin{array}{c}\text { EQL } \\
(\mathrm{ppm})\end{array} \\
\end{array}$ & $\begin{array}{c}\text { Linear Dynamic } \\
\text { Range (ppm) }\end{array}$ \\
\hline$\overline{\mathrm{Ag}}$ & 328.068 & 0.00206 & 0.01 & $0.003-150$ \\
\hline $\mathrm{Al}$ & 308.215 & 0.00984 & 0.05 & $0.025-500$ \\
\hline As & 193.696 & 0.02291 & 0.10 & $0.050-250$ \\
\hline $\mathrm{B}$ & 249.678 & 0.00626 & 0.05 & $0.006-150$ \\
\hline $\mathrm{Ba}$ & 455.403 & 0.00031 & 0.05 & $0.001-100$ \\
\hline $\mathrm{Be}$ & 313.042 & 0.00025 & 0.005 & $0.001-150$ \\
\hline $\mathrm{Bi}$ & 223.061 & 0.02461 & 0.10 & $0.030-500$ \\
\hline $\mathrm{Ca}$ & 317.933 & 0.00717 & 0.10 & $0.010-500$ \\
\hline $\mathrm{Cd}$ & 226.502 & 0.00186 & 0.01 & $0.004-200$ \\
\hline $\mathrm{Ce}$ & 413.765 & 0.03011 & 0.10 & $0.050-250$ \\
\hline Co & 228.616 & 0.00341 & 0.02 & $0.003-150$ \\
\hline $\mathrm{Cr}$ & 267.7 .16 & 0.00204 & 0.01 & $0.005-150$ \\
\hline $\mathrm{Cu}$ & 324.754 & 0.00159 & 0.01 & $0.002-150$ \\
\hline $\mathrm{Eu}$ & 393.948 & 0.00411 & 0.05 & $0.005-100$ \\
\hline $\mathrm{Fe}$ & 259.940 & 0.00261 & 0.05 & $0.005-150$ \\
\hline $\mathrm{K}$ & 766.491 & 0.32211 & 0.50 & $0.400-1000$ \\
\hline $\mathrm{La}$ & 408.672 & 0.00231 & 0.05 & $0.004-150$ \\
\hline $\mathrm{Li}$ & 670.784 & 0.00063 & 0.01 & $0.006-200$ \\
\hline $\mathrm{Mg}$ & 279.079 & 0.01041 & 0.10 & $0.015-500$ \\
\hline $\mathrm{Mn}$ & 257.610 & 0.00042 & 0.01 & $0.001-150$ \\
\hline Mo & 202.030 & 0.00552 & 0.05 & $0.005-200$ \\
\hline $\mathrm{Na}$ & 588.995 & 0.00698 & 0.10 & $0.010-200$ \\
\hline $\mathrm{Nd}$ & 401.225 & 0.00469 & 0.10 & $0.010-200$ \\
\hline $\mathrm{Ni}$ & 231.604 & 0.01411 & 0.02 & $0.010-200$ \\
\hline$P$ & 178.287 & 0.03041 & 0.20 & $0.060-250$ \\
\hline $\mathrm{Pb}$ & 220.353 & 0.02721 & 0.10 & $0.025-200$ \\
\hline$S$ & 182.040 & 0.01971 & 0.10 & $0.080-500$ \\
\hline $\mathrm{Sb}$ & 206.838 & 0.01811 & 0.06 & $0.050-200$ \\
\hline $\mathrm{Se}$ & 196.026 & 0.03491 & 0.10 & $0.050-250$ \\
\hline $\mathrm{Si}$ & 251.611 & 0.00555 & 0.05 & $0.010-500$ \\
\hline $\mathrm{Sm}$ & 443.430 & 0.00943 & 0.10 & $0.020-100$ \\
\hline $\mathrm{Sr}$ & 421.552 & 0.00031 & 0.01 & $0.001-100$ \\
\hline $\mathrm{Th}$ & 283.730 & 0.00316 & 0.05 & $0.030-150$ \\
\hline $\mathrm{Ti}$ & 334.941 & 0.00112 & 0.01 & $0.002-200$ \\
\hline $\mathrm{Tl}$ & 190.864 & 0.03411 & 0.20 & $0.050-500$ \\
\hline $\bar{U}$ & 385.958 & 0.03451 & 0.50 & $0.100-300$ \\
\hline $\mathrm{V}$ & 292.402 & 0.00256 & 0.05 & $0.002-200$ \\
\hline $\mathrm{Zn}$ & 213.856 & 0.00238 & 0.01 & $0.004-150$ \\
\hline $\mathrm{Zr}$ & 339.198 & 0.00202 & 0.01 & $0.003-250$ \\
\hline
\end{tabular}

A.1 
Table A.2. Strontium Loading Data for PNNL Disk Test Using Actual N-Springs Water

\begin{tabular}{|c|c|c|c|c|c|c|c||}
\hline $\begin{array}{c}\text { Time } \\
(\mathrm{min})\end{array}$ & $\begin{array}{c}\text { Sample } \\
\text { Number }\end{array}$ & $\begin{array}{c}\text { Vol. } \\
(\mathrm{BV})\end{array}$ & $\begin{array}{c}\text { Vol. } \\
(\mathrm{mL})\end{array}$ & $\begin{array}{c}\text { Strontium } \\
(\mathrm{mg} / \mathrm{L})\end{array}$ & $\begin{array}{c}\text { Strontium } \\
(\mathrm{cnts})\end{array}$ & $\begin{array}{c}\text { Strontium } \\
\left(\mathrm{C} / \mathrm{C}_{0}\right)\end{array}$ & $\begin{array}{c}\text { Loaded } \\
(\mathrm{mmol} \mathrm{Sr})\end{array}$ \\
\hline \hline 0 & $96 \mathrm{~B}-\mathrm{Fd}$ & 0.0 & 0.0 & $1.30 \mathrm{E}-01$ & $1.40 \mathrm{E}+04$ & $1.00 \mathrm{E}+00$ & $1.80 \mathrm{E}-03$ \\
\hline 5 & $96 \mathrm{~B}-01$ & 29.3 & 28.8 & $9.27 \mathrm{E}-06$ & $<1.00 \mathrm{E}+00$ & $<7.13 \mathrm{E}-05$ & $2.13 \mathrm{E}-05$ \\
\hline 10 & $96 \mathrm{~B}-02$ & 60.9 & 59.8 & $9.27 \mathrm{E}-06$ & $<1.00 \mathrm{E}+00$ & $<7.13 \mathrm{E}-05$ & $6.73 \mathrm{E}-05$ \\
\hline 15 & $96 \mathrm{~B}-03$ & 92.6 & 91.0 & $9.27 \mathrm{E}-06$ & $<1.00 \mathrm{E}+00$ & $<7.13 \mathrm{E}-05$ & $1.14 \mathrm{E}-04$ \\
\hline 20 & $96 \mathrm{~B}-04$ & 123.6 & 121.4 & $9.27 \mathrm{E}-06$ & $<1.00 \mathrm{E}+00$ & $<7.13 \mathrm{E}-05$ & $1.59 \mathrm{E}-04$ \\
\hline 25 & $96 \mathrm{~B}-05$ & 155.2 & 152.4 & $9.27 \mathrm{E}-06$ & $<1.00 \mathrm{E}+00$ & $<7.13 \mathrm{E}-05$ & $2.05 \mathrm{E}-04$ \\
\hline 30 & $96 \mathrm{~B}-06$ & 186.5 & 183.1 & $9.27 \mathrm{E}-06$ & $<1.00 \mathrm{E}+00$ & $<7.13 \mathrm{E}-05$ & $2.50 \mathrm{E}-04$ \\
\hline 35 & $96 \mathrm{~B}-07$ & 217.5 & 213.5 & $9.27 \mathrm{E}-06$ & $<1.00 \mathrm{E}+00$ & $<7.13 \mathrm{E}-05$ & $2.95 \mathrm{E}-04$ \\
\hline 40 & $96 \mathrm{~B}-08$ & 248.9 & 244.4 & $9.27 \mathrm{E}-06$ & $<1.00 \mathrm{E}+00$ & $<7.13 \mathrm{E}-05$ & $3.41 \mathrm{E}-04$ \\
\hline 45 & $96 \mathrm{~B}-09$ & 279.8 & 274.7 & $9.27 \mathrm{E}-06$ & $<1.00 \mathrm{E}+00$ & $<7.13 \mathrm{E}-05$ & $3.86 \mathrm{E}-04$ \\
\hline 50 & $96 \mathrm{~B}-10$ & 310.8 & 305.1 & $9.27 \mathrm{E}-06$ & $<1.00 \mathrm{E}+00$ & $<7.13 \mathrm{E}-05$ & $4.31 \mathrm{E}-04$ \\
\hline 55 & $96 \mathrm{~B}-11$ & 342.3 & 336.1 & $9.27 \mathrm{E}-06$ & $<1.00 \mathrm{E}+00$ & $<7.13 \mathrm{E}-05$ & $4.77 \mathrm{E}-04$ \\
\hline 60 & $96 \mathrm{~B}-12$ & 373.4 & 366.6 & $9.27 \mathrm{E}-06$ & $<1.00 \mathrm{E}+00$ & $<7.13 \mathrm{E}-05$ & $5.23 \mathrm{E}-04$ \\
\hline 70 & $96 \mathrm{~B}-13$ & 436.6 & 428.6 & $2.98 \mathrm{E}-03$ & $3.22 \mathrm{E}+02$ & $2.30 \mathrm{E}-02$ & $6.13 \mathrm{E}-04$ \\
\hline 80 & $96 \mathrm{~B}-14$ & 500.1 & 491.0 & $1.03 \mathrm{E}-02$ & $1.11 \mathrm{E}+03$ & $7.92 \mathrm{E}-02$ & $7.01 \mathrm{E}-04$ \\
\hline 90 & $96 \mathrm{~B}-15$ & 564.7 & 554.4 & $1.90 \mathrm{E}-02$ & $2.05 \mathrm{E}+03$ & $1.46 \mathrm{E}-01$ & $7.85 \mathrm{E}-04$ \\
\hline 100 & $96 \mathrm{~B}-16$ & 627.5 & 616.1 & $2.84 \mathrm{E}-02$ & $3.07 \mathrm{E}+03$ & $2.19 \mathrm{E}-01$ & $8.60 \mathrm{E}-04$ \\
\hline 110 & $96 \mathrm{~B}-17$ & 694.1 & 681.5 & $3.80 \mathrm{E}-02$ & $4.10 \mathrm{E}+03$ & $2.93 \mathrm{E}-01$ & $9.32 \mathrm{E}-04$ \\
\hline 120 & $96 \mathrm{~B}-18$ & 757.8 & 744.0 & $4.84 \mathrm{E}-02$ & $5.22 \mathrm{E}+03$ & $3.72 \mathrm{E}-01$ & $9.94 \mathrm{E}-04$ \\
\hline 130 & $96 \mathrm{~B}-19$ & 822.6 & 807.6 & $5.62 \mathrm{E}-02$ & $6.06 \mathrm{E}+03$ & $4.32 \mathrm{E}-01$ & $1.05 \mathrm{E}-03$ \\
\hline 150 & $96 \mathrm{~B}-20$ & 950.9 & 933.5 & $7.13 \mathrm{E}-02$ & $7.69 \mathrm{E}+03$ & $5.48 \mathrm{E}-01$ & $1.15 \mathrm{E}-03$ \\
\hline 180 & $96 \mathrm{~B}-21$ & 1142.2 & 1121.3 & $9.12 \mathrm{E}-02$ & $9.83 \mathrm{E}+03$ & $7.01 \mathrm{E}-01$ & $1.25 \mathrm{E}-03$ \\
\hline 195 & $96 \mathrm{~B}-22$ & 1239.1 & 1216.5 & $9.17 \mathrm{E}-02$ & $9.89 \mathrm{E}+03$ & $7.06 \mathrm{E}-01$ & $1.29 \mathrm{E}-03$ \\
\hline
\end{tabular}


Table A.3. Strontium Elution Data for PNNL Disk Test Using Actual N-Springs Water

\begin{tabular}{||c|c|c|c|c|c|c|c||}
\hline $\begin{array}{c}\text { Time } \\
(\mathrm{min})\end{array}$ & $\begin{array}{c}\text { Sample } \\
\text { Number }\end{array}$ & $\begin{array}{c}\text { Vol. } \\
(\mathrm{BV})\end{array}$ & $\begin{array}{c}\text { Vol. } \\
(\mathrm{mL})\end{array}$ & $\begin{array}{c}\text { Strontium } \\
(\mathrm{mg} / \mathrm{L})\end{array}$ & $\begin{array}{c}\text { Strontium } \\
(\mathrm{cnts})\end{array}$ & $\begin{array}{c}\text { Strontium } \\
\left(\mathrm{C} / \mathrm{C}_{0}\right)\end{array}$ & $\begin{array}{c}\text { Eluted } \\
(\mathrm{mmol} \mathrm{Sr})\end{array}$ \\
\hline \hline 1 & $96 \mathrm{~B}-23$ & 5.0 & 4.9 & $9.83 \mathrm{E}-01$ & $1.06 \mathrm{E}+05$ & $7.56 \mathrm{E}+00$ & $2.74 \mathrm{E}-05$ \\
\hline 2 & $96 \mathrm{~B}-24$ & 11.5 & 11.3 & $5.22 \mathrm{E}+00$ & $5.63 \mathrm{E}+05$ & $4.02 \mathrm{E}+01$ & $2.55 \mathrm{E}-04$ \\
\hline 3 & $96 \mathrm{~B}-25$ & 18.0 & 17.6 & $9.46 \mathrm{E}+00$ & $1.02 \mathrm{E}+06$ & $7.27 \mathrm{E}+01$ & $7.83 \mathrm{E}-04$ \\
\hline 4 & $96 \mathrm{~B}-26$ & 24.9 & 24.5 & $3.22 \mathrm{E}+00$ & $3.47 \mathrm{E}+05$ & $2.47 \mathrm{E}+01$ & $1.28 \mathrm{E}-03$ \\
\hline 5 & $96 \mathrm{~B}-27$ & 31.1 & 30.6 & $8.84 \mathrm{E}-01$ & $9.54 \mathrm{E}+04$ & $6.80 \mathrm{E}+00$ & $1.42 \mathrm{E}-03$ \\
\hline 6 & $96 \mathrm{~B}-28$ & 35.4 & 34.8 & $5.46 \mathrm{E}-01$ & $5.89 \mathrm{E}+04$ & $4.20 \mathrm{E}+00$ & $1.45 \mathrm{E}-03$ \\
\hline 7 & $96 \mathrm{~B}-29$ & 40.7 & 39.9 & $3.12 \mathrm{E}-01$ & $3.36 \mathrm{E}+04$ & $2.40 \mathrm{E}+00$ & $1.48 \mathrm{E}-03$ \\
\hline 8 & $96 \mathrm{~B}-30$ & 47.2 & 46.3 & $2.13 \mathrm{E}-01$ & $2.29 \mathrm{E}+04$ & $1.64 \mathrm{E}+00$ & $1.50 \mathrm{E}-03$ \\
\hline 9 & $96 \mathrm{~B}-31$ & 52.5 & 51.6 & $2.01 \mathrm{E}-01$ & $2.17 \mathrm{E}+04$ & $1.55 \mathrm{E}+00$ & $1.51 \mathrm{E}-03$ \\
\hline 10 & $96 \mathrm{~B}-32$ & 59.2 & 58.1 & $1.36 \mathrm{E}-01$ & $1.46 \mathrm{E}+04$ & $1.04 \mathrm{E}+00$ & $1.52 \mathrm{E}-03$ \\
\hline 11 & $96 \mathrm{~B}-33$ & 65.0 & 63.9 & $5.91 \mathrm{E}-02$ & $6.37 \mathrm{E}+03$ & $4.54 \mathrm{E}-01$ & $1.53 \mathrm{E}-03$ \\
\hline 12 & $96 \mathrm{~B}-34$ & 72.5 & 71.1 & $3.83 \mathrm{E}-02$ & $4.14 \mathrm{E}+03$ & $2.95 \mathrm{E}-01$ & $1.53 \mathrm{E}-03$ \\
\hline 14 & $96 \mathrm{~B}-35$ & 82.0 & 80.5 & $2.89 \mathrm{E}-02$ & $3.11 \mathrm{E}+03$ & $2.22 \mathrm{E}-01$ & $1.54 \mathrm{E}-03$ \\
\hline 16 & $96 \mathrm{~B}-36$ & 94.8 & 93.1 & $2.05 \mathrm{E}-02$ & $2.21 \mathrm{E}+03$ & $1.58 \mathrm{E}-01$ & $1.54 \mathrm{E}-03$ \\
\hline 18 & $96 \mathrm{~B}-37$ & 109.0 & 107.0 & $1.52 \mathrm{E}-02$ & $1.64 \mathrm{E}+03$ & $1.17 \mathrm{E}-01$ & $1.54 \mathrm{E}-03$ \\
\hline 20 & $96 \mathrm{~B}-38$ & 123.8 & 121.6 & $1.05 \mathrm{E}-02$ & $1.14 \mathrm{E}+03$ & $8.10 \mathrm{E}-02$ & $1.55 \mathrm{E}-03$ \\
\hline
\end{tabular}

Table A.4. Strontium Loading Data for PADU Cartridge Field Demonstration at N-Springs

\begin{tabular}{|c|c|r|r|r|c|c|c||}
\hline $\begin{array}{c}\text { Time } \\
(\mathrm{min})\end{array}$ & $\begin{array}{c}\text { Sample } \\
\text { Number }\end{array}$ & $\begin{array}{c}\text { Vol. } \\
(\mathrm{BV})\end{array}$ & $\begin{array}{c}\text { Vol. } \\
(\mathrm{L})\end{array}$ & $\begin{array}{c}\text { Strontium } \\
(\mathrm{mg} / \mathrm{L})\end{array}$ & $\begin{array}{c}\text { Strontium } \\
(\mu \mathrm{g} / \mathrm{L})\end{array}$ & $\begin{array}{c}\text { Strontium } \\
\left(\mathrm{C} / \mathrm{C}_{0}\right)\end{array}$ & $\begin{array}{c}\text { Loaded } \\
(\mathrm{mmol} \mathrm{Sr})\end{array}$ \\
\hline \hline 0 & C3Sr-Fd & 0.0 & 0.0 & $1.31 \mathrm{E}-01$ & $1.31 \mathrm{E}+02$ & $1.00 \mathrm{E}+00$ & $1.19 \mathrm{E}+00$ \\
\hline 6 & C3Sr-01 & 170.5 & 83.2 & $2.00 \mathrm{E}-03$ & $2.00 \mathrm{E}+00$ & $1.53 \mathrm{E}-02$ & $6.10 \mathrm{E}-02$ \\
\hline 16 & C3Sr-02 & 449.6 & 219.2 & $8.90 \mathrm{E}-03$ & $8.90 \mathrm{E}+00$ & $6.82 \mathrm{E}-02$ & $2.55 \mathrm{E}-01$ \\
\hline 31 & C3Sr-03 & 837.2 & 408.2 & $3.14 \mathrm{E}-02$ & $3.14 \mathrm{E}+01$ & $2.41 \mathrm{E}-01$ & $4.93 \mathrm{E}-01$ \\
\hline 46 & C3Sr-04 & 1255.8 & 612.4 & $5.12 \mathrm{E}-02$ & $5.12 \mathrm{E}+01$ & $3.92 \mathrm{E}-01$ & $7.01 \mathrm{E}-01$ \\
\hline 61 & $\mathrm{C} 3 \mathrm{Sr}-05$ & 1643.4 & 801.4 & $6.69 \mathrm{E}-02$ & $6.69 \mathrm{E}+01$ & $5.12 \mathrm{E}-01$ & $8.56 \mathrm{E}-01$ \\
\hline
\end{tabular}


Table A.5. Barium Loading Data for PADU Cartridge Field Demonstration at N-Springs

\begin{tabular}{|c|c|c|c|c|c|c|c||}
\hline $\begin{array}{c}\text { Time } \\
(\mathrm{min})\end{array}$ & $\begin{array}{c}\text { Sample } \\
\text { Number }\end{array}$ & $\begin{array}{c}\text { Vol. } \\
(\mathrm{BV})\end{array}$ & $\begin{array}{c}\text { Vol. } \\
(\mathrm{L})\end{array}$ & $\begin{array}{c}\text { Barium } \\
(\mathrm{mg} / \mathrm{L})\end{array}$ & $\begin{array}{c}\text { Barium } \\
(\mu \mathrm{g} / \mathrm{L})\end{array}$ & $\begin{array}{c}\text { Barium } \\
\left(\mathrm{C} / \mathrm{C}_{0}\right)\end{array}$ & $\begin{array}{c}\text { Loaded } \\
(\mathrm{mmol} \mathrm{Ba})\end{array}$ \\
\hline \hline 0 & $\mathrm{C} 3 \mathrm{Ba}-\mathrm{Fd}$ & 0.0 & 0.0 & $1.54 \mathrm{E}-02$ & $1.54 \mathrm{E}+01$ & $1.00 \mathrm{E}+00$ & $8.99 \mathrm{E}-02$ \\
\hline 6 & $\mathrm{C} 3 \mathrm{Ba}-01$ & 170.5 & 83.2 & $<1.00 \mathrm{E}-05$ & $<1.00 \mathrm{E}-02$ & $0.00 \mathrm{E}+00$ & $4.66 \mathrm{E}-03$ \\
\hline 16 & $\mathrm{C} 3 \mathrm{Ba}-02$ & 449.6 & 219.2 & $<1.00 \mathrm{E}-05$ & $<1.00 \mathrm{E}-02$ & $0.00 \mathrm{E}+00$ & $1.99 \mathrm{E}-02$ \\
\hline 31 & $\mathrm{C} 3 \mathrm{Ba}-03$ & 837.2 & 408.2 & $<1.00 \mathrm{E}-05$ & $<1.00 \mathrm{E}-02$ & $0.00 \mathrm{E}+00$ & $4.11 \mathrm{E}-02$ \\
\hline 46 & $\mathrm{C} 3 \mathrm{Ba}-04$ & 1255.8 & 612.4 & $<1.00 \mathrm{E}-05$ & $<1.00 \mathrm{E}-02$ & $0.00 \mathrm{E}+00$ & $6.40 \mathrm{E}-02$ \\
\hline 61 & $\mathrm{C} 3 \mathrm{Ba}-05$ & 1643.4 & 801.4 & $<1.00 \mathrm{E}-05$ & $<1.00 \mathrm{E}-02$ & $0.00 \mathrm{E}+00$ & $8.52 \mathrm{E}-02$ \\
\hline
\end{tabular}

Table A.6. Calcium Loading Data for PADU Cartridge Field Demonstration at N-Springs

\begin{tabular}{||c|c|r|r|c|c|c|c||}
\hline \hline $\begin{array}{c}\text { Time } \\
(\mathrm{min})\end{array}$ & $\begin{array}{c}\text { Sample } \\
\text { Number }\end{array}$ & $\begin{array}{c}\text { Vol. } \\
(\mathrm{BV})\end{array}$ & $\begin{array}{c}\text { Vol. } \\
(\mathrm{L})\end{array}$ & $\begin{array}{c}\text { Calcium } \\
(\mathrm{mg} / \mathrm{L})\end{array}$ & $\begin{array}{c}\text { Calcium } \\
(\mathrm{mg} / \mathrm{L})\end{array}$ & $\begin{array}{c}\text { Calcium } \\
\left(\mathrm{C} / \mathrm{C}_{0}\right)\end{array}$ & $\begin{array}{c}\text { Loaded } \\
(\mathrm{mmol} \mathrm{Ca})\end{array}$ \\
\hline \hline 0 & $\mathrm{C} 3 \mathrm{Ca}-\mathrm{Fd}$ & 0.0 & 0.0 & $2.92 \mathrm{E}+01$ & $2.92 \mathrm{E}+01$ & $1.00 \mathrm{E}+00$ & $5.83 \mathrm{E}+02$ \\
\hline 6 & $\mathrm{C} 3 \mathrm{Ca}-01$ & 170.5 & 83.2 & $7.29 \mathrm{E}-01$ & $7.29 \mathrm{E}-01$ & $2.50 \mathrm{E}-02$ & $2.95 \mathrm{E}+01$ \\
\hline 16 & $\mathrm{C} 3 \mathrm{Ca}-02$ & 449.6 & 219.2 & $5.79 \mathrm{E}+00$ & $5.79 \mathrm{E}+00$ & $1.99 \mathrm{E}-01$ & $1.18 \mathrm{E}+02$ \\
\hline 31 & $\mathrm{C} 3 \mathrm{Ca}-03$ & 837.2 & 408.2 & $1.84 \mathrm{E}+01$ & $1.84 \mathrm{E}+01$ & $6.30 \mathrm{E}-01$ & $1.98 \mathrm{E}+02$ \\
\hline 46 & $\mathrm{C} 3 \mathrm{Ca}-04$ & 1255.8 & 612.4 & $2.38 \mathrm{E}+01$ & $2.38 \mathrm{E}+01$ & $8.16 \mathrm{E}-01$ & $2.39 \mathrm{E}+02$ \\
\hline 61 & $\mathrm{C} 3 \mathrm{Ca}-05$ & 1643.4 & 801.4 & $2.56 \mathrm{E}+01$ & $2.56 \mathrm{E}+01$ & $8.77 \mathrm{E}-01$ & $2.60 \mathrm{E}+02$ \\
\hline
\end{tabular}

Table A.7. Magnesium Loading Data for PADU Cartridge Field Demonstration at N-Springs

\begin{tabular}{||c|c|r|r|c|c|c|c||}
\hline $\begin{array}{c}\text { Time } \\
(\mathrm{min})\end{array}$ & $\begin{array}{c}\text { Sample } \\
\text { Number }\end{array}$ & $\begin{array}{c}\text { Vol. } \\
(\mathrm{BV})\end{array}$ & $\begin{array}{c}\text { Vol. } \\
(\mathrm{L})\end{array}$ & $\begin{array}{c}\text { Magnesium } \\
(\mathrm{mg} / \mathrm{L})\end{array}$ & $\begin{array}{c}\text { Magnesium } \\
(\mathrm{mg} / \mathrm{L})\end{array}$ & $\begin{array}{c}\text { Magnesium } \\
\left(\mathrm{C} / \mathrm{C}_{0}\right)\end{array}$ & $\begin{array}{c}\text { Loaded } \\
(\mathrm{mmol} \mathrm{Mg})\end{array}$ \\
\hline \hline 0 & $\mathrm{C} 3 \mathrm{Mg}-\mathrm{Fd}$ & 0.0 & 0.0 & $5.25 \mathrm{E}+00$ & $5.25 \mathrm{E}+00$ & $1.00 \mathrm{E}+00$ & $1.73 \mathrm{E}+02$ \\
\hline 6 & $\mathrm{C} 3 \mathrm{Mg}-01$ & 170.5 & 83.2 & $2.96 \mathrm{E}-01$ & $2.96 \mathrm{E}-01$ & $5.64 \mathrm{E}-02$ & $8.48 \mathrm{E}+00$ \\
\hline 16 & $\mathrm{C} 3 \mathrm{Mg}-02$ & 449.6 & 219.2 & $3.19 \mathrm{E}+00$ & $3.19 \mathrm{E}+00$ & $6.08 \mathrm{E}-01$ & $2.81 \mathrm{E}+01$ \\
\hline 31 & $\mathrm{C} 3 \mathrm{Mg}-03$ & 837.2 & 408.2 & $6.41 \mathrm{E}+00$ & $6.41 \mathrm{E}+00$ & $1.22 \mathrm{E}+00$ & $3.16 \mathrm{E}+01$ \\
\hline 46 & $\mathrm{C} 3 \mathrm{Mg}-04$ & 1255.8 & 612.4 & $5.70 \mathrm{E}+00$ & $5.70 \mathrm{E}+00$ & $1.09 \mathrm{E}+00$ & $2.48 \mathrm{E}+01$ \\
\hline 61 & $\mathrm{C} 3 \mathrm{Mg}-05$ & 1643.4 & 801.4 & $5.33 \mathrm{E}+00$ & $5.33 \mathrm{E}+00$ & $1.01 \mathrm{E}+00$ & $2.28 \mathrm{E}+01$ \\
\hline
\end{tabular}


Table A.8. Sodium Loading Data for PADU Cartridge Field Demonstration at N-Springs

\begin{tabular}{|c|c|c|c|c|c|c|c|}
\hline $\begin{array}{c}\text { Time } \\
(\mathrm{min})\end{array}$ & $\begin{array}{c}\text { Sample } \\
\text { Number }\end{array}$ & $\begin{array}{c}\text { Vol. } \\
(\mathrm{BV})\end{array}$ & $\begin{array}{c}\text { Vol. } \\
(\mathrm{L})\end{array}$ & $\begin{array}{c}\text { Sodium } \\
(\mathrm{mg} / \mathrm{L})\end{array}$ & $\begin{array}{c}\text { Sodium } \\
(\mu \mathrm{g} / \mathrm{L})\end{array}$ & $\begin{array}{c}\text { Sodium } \\
\left(\mathrm{C} / \mathrm{C}_{0}\right)\end{array}$ & $\begin{array}{c}\text { Loaded } \\
(\mathrm{mmol} \mathrm{Na})\end{array}$ \\
\hline \hline 0 & $\mathrm{C} 3 \mathrm{Na}-\mathrm{Fd}$ & 0.0 & 0.0 & $5.94 \mathrm{E}+00$ & $5.94 \mathrm{E}+03$ & $1.00 \mathrm{E}+00$ & $2.07 \mathrm{E}+02$ \\
\hline 6 & $\mathrm{C} 3 \mathrm{Na}-01$ & 170.5 & 83.2 & $5.12 \mathrm{E}+01$ & $5.12 \mathrm{E}+04$ & $8.62 \mathrm{E}+00$ & $-8.18 \mathrm{E}+01$ \\
\hline 16 & $\mathrm{C} 3 \mathrm{Na}-02$ & 449.6 & 219.2 & $3.58 \mathrm{E}+01$ & $3.58 \mathrm{E}+04$ & $6.04 \mathrm{E}+00$ & $-3.04 \mathrm{E}+02$ \\
\hline 31 & $\mathrm{C} 3 \mathrm{Na}-03$ & 837.2 & 408.2 & $1.39 \mathrm{E}+01$ & $1.39 \mathrm{E}+04$ & $2.34 \mathrm{E}+00$ & $-4.60 \mathrm{E}+02$ \\
\hline 46 & $\mathrm{C} 3 \mathrm{Na}-04$ & 1255.8 & 612.4 & $9.49 \mathrm{E}+00$ & $9.49 \mathrm{E}+03$ & $1.60 \mathrm{E}+00$ & $-5.11 \mathrm{E}+02$ \\
\hline 61 & $\mathrm{C} 3 \mathrm{Na}-05$ & 1643.4 & -801.4 & $8.39 \mathrm{E}+00$ & $8.39 \mathrm{E}+03$ & $1.41 \mathrm{E}+00$ & $-5.35 \mathrm{E}+02$ \\
\hline
\end{tabular}

Table A.9. Strontium Loading Data for 3M Laboratory Cartridge Test Using Simulant

\begin{tabular}{|c|c|c|c|c|c|c|c||}
\hline $\begin{array}{c}\text { Time } \\
(\mathrm{min})\end{array}$ & $\begin{array}{c}\text { Sample } \\
\text { Number }\end{array}$ & $\begin{array}{c}\text { Vol. } \\
(\mathrm{BV})\end{array}$ & $\begin{array}{c}\text { Vol. } \\
(\mathrm{L})\end{array}$ & $\begin{array}{c}\text { Strontium } \\
(\mathrm{mg} / \mathrm{L})\end{array}$ & $\begin{array}{c}\text { Strontium } \\
(\mu \mathrm{g} / \mathrm{L})\end{array}$ & $\begin{array}{c}\text { Strontium } \\
\left(\mathrm{C} / \mathrm{C}_{0}\right)\end{array}$ & $\begin{array}{c}\text { Loaded } \\
(\mathrm{mmol} \mathrm{Sr})\end{array}$ \\
\hline \hline 0 & $3 \mathrm{MSr}-\mathrm{Fd}$ & 0.0 & 0.0 & $1.47 \mathrm{E}-01$ & $1.47 \mathrm{E}+02$ & $1.00 \mathrm{E}+00$ & $8.06 \mathrm{E}-01$ \\
\hline 15 & $3 \mathrm{MSr}-01$ & 268.5 & 43.6 & $0.00 \mathrm{E}+00$ & $0.00 \mathrm{E}+00$ & $0.00 \mathrm{E}+00$ & $3.66 \mathrm{E}-02$ \\
\hline 30 & $3 \mathrm{MSr}-02$ & 540.2 & 87.8 & $1.70 \mathrm{E}-02$ & $1.70 \mathrm{E}+01$ & $1.16 \mathrm{E}-01$ & $1.06 \mathrm{E}-01$ \\
\hline 45 & $3 \mathrm{MSr}-03$ & 808.7 & 131.4 & $4.90 \mathrm{E}-02$ & $4.90 \mathrm{E}+01$ & $3.33 \mathrm{E}-01$ & $1.63 \mathrm{E}-01$ \\
\hline 60 & $3 \mathrm{MSr}-04$ & 1072.7 & 174.4 & $7.90 \mathrm{E}-02$ & $7.90 \mathrm{E}+01$ & $5.37 \mathrm{E}-01$ & $2.04 \mathrm{E}-01$ \\
\hline 75 & $3 \mathrm{MSr}-05$ & 1331.1 & 216.4 & $9.80 \mathrm{E}-02$ & $9.80 \mathrm{E}+01$ & $6.67 \mathrm{E}-01$ & $2.32 \mathrm{E}-01$ \\
\hline 90 & $3 \mathrm{MSr}-06$ & 1584.2 & 257.5 & $1.10 \mathrm{E}-01$ & $1.10 \mathrm{E}+02$ & $7.48 \mathrm{E}-01$ & $2.52 \mathrm{E}-01$ \\
\hline 105 & $3 \mathrm{MSr}-07$ & 1833.0 & 297.9 & $1.21 \mathrm{E}-01$ & $1.21 \mathrm{E}+02$ & $8.23 \mathrm{E}-01$ & $2.67 \mathrm{E}-01$ \\
\hline 120 & $3 \mathrm{MSr}-08$ & 2077.2 & 337.6 & $1.27 \mathrm{E}-01$ & $1.27 \mathrm{E}+02$ & $8.64 \mathrm{E}-01$ & $2.77 \mathrm{E}-01$ \\
\hline 135 & $3 \mathrm{MSr}-09$ & 2309.2 & 375.3 & $1.29 \mathrm{E}-01$ & $1.29 \mathrm{E}+02$ & $8.78 \mathrm{E}-01$ & $2.85 \mathrm{E}-01$ \\
\hline 150 & $3 \mathrm{MSr}-10$ & 2529.1 & 411.1 & $1.31 \mathrm{E}-01$ & $1.31 \mathrm{E}+02$ & $8.91 \mathrm{E}-01$ & $2.92 \mathrm{E}-01$ \\
\hline 165 & $3 \mathrm{MSr}-11$ & 2745.1 & 446.2 & $1.34 \mathrm{E}-01$ & $1.34 \mathrm{E}+02$ & $9.12 \mathrm{E}-01$ & $2.98 \mathrm{E}-01$ \\
\hline 180 & $3 \mathrm{MSr}-12$ & 2957.0 & 480.6 & $1.35 \mathrm{E}-01$ & $1.35 \mathrm{E}+02$ & $9.18 \mathrm{E}-01$ & $3.03 \mathrm{E}-01$ \\
\hline \hline
\end{tabular}


Table A.10. Calcium Loading Data for 3M Laboratory Cartridge Test Using Simulant

\begin{tabular}{||c|c|c|c|c|c|c|c||}
\hline $\begin{array}{c}\text { Time } \\
(\mathrm{min})\end{array}$ & $\begin{array}{c}\text { Sample } \\
\text { Number }\end{array}$ & $\begin{array}{c}\text { Vol. } \\
(\mathrm{BV})\end{array}$ & $\begin{array}{c}\text { Vol. } \\
(\mathrm{L})\end{array}$ & $\begin{array}{c}\text { Calcium } \\
(\mathrm{mg} / \mathrm{L})\end{array}$ & $\begin{array}{c}\text { Calcium } \\
(\mu \mathrm{g} / \mathrm{L})\end{array}$ & $\begin{array}{c}\text { Calcium } \\
\left(\mathrm{C} / \mathrm{C}_{0}\right)\end{array}$ & $\begin{array}{c}\text { Loaded } \\
(\mathrm{mmol} \mathrm{Ca})\end{array}$ \\
\hline \hline 0 & $3 \mathrm{MCa}-\mathrm{Fd}$ & 0.0 & 0.0 & $2.91 \mathrm{E}+01$ & $2.91 \mathrm{E}+04$ & $1.00 \mathrm{E}+00$ & $3.49 \mathrm{E}+02$ \\
\hline 15 & $3 \mathrm{MCa}-01$ & 268.5 & 43.6 & $4.70 \mathrm{E}-01$ & $4.70 \mathrm{E}+02$ & $1.62 \mathrm{E}-02$ & $1.56 \mathrm{E}+01$ \\
\hline 30 & $3 \mathrm{MCa}-02$ & 540.2 & 87.8 & $8.70 \mathrm{E}+00$ & $8.70 \mathrm{E}+03$ & $2.99 \mathrm{E}-01$ & $4.26 \mathrm{E}+01$ \\
\hline 45 & $3 \mathrm{MCa}-03$ & 808.7 & 131.4 & $2.07 \mathrm{E}+01$ & $2.07 \mathrm{E}+04$ & $7.11 \mathrm{E}-01$ & $5.83 \mathrm{E}+01$ \\
\hline 60 & $3 \mathrm{MCa}-04$ & 1072.7 & 174.4 & $2.58 \mathrm{E}+01$ & $2.58 \mathrm{E}+04$ & $8.87 \mathrm{E}-01$ & $6.45 \mathrm{E}+01$ \\
\hline 75 & $3 \mathrm{MCa}-05$ & 1331.1 & 216.4 & $2.72 \mathrm{E}+01$ & $2.72 \mathrm{E}+04$ & $9.35 \mathrm{E}-01$ & $6.73 \mathrm{E}+01$ \\
\hline 90 & $3 \mathrm{MCa}-06$ & 1584.2 & 257.5 & $2.78 \mathrm{E}+01$ & $2.78 \mathrm{E}+04$ & $9.55 \mathrm{E}-01$ & $6.89 \mathrm{E}+01$ \\
\hline 105 & $3 \mathrm{MCa}-07$ & 1833.0 & 297.9 & $2.81 \mathrm{E}+01$ & $2.81 \mathrm{E}+04$ & $9.66 \mathrm{E}-01$ & $7.01 \mathrm{E}+01$ \\
\hline 120 & $3 \mathrm{MCa}-08$ & 2077.2 & 337.6 & $2.82 \mathrm{E}+01$ & $2.82 \mathrm{E}+04$ & $9.69 \mathrm{E}-01$ & $7.10 \mathrm{E}+01$ \\
\hline 135 & $3 \mathrm{MCa}-09$ & 2309.2 & 375.3 & $2.82 \mathrm{E}+01$ & $2.82 \mathrm{E}+04$ & $9.69 \mathrm{E}-01$ & $7.19 \mathrm{E}+01$ \\
\hline 150 & $3 \mathrm{MCa}-10$ & 2529.1 & 411.1 & $2.83 \mathrm{E}+01$ & $2.83 \mathrm{E}+04$ & $9.73 \mathrm{E}-01$ & $7.26 \mathrm{E}+01$ \\
\hline 165 & $3 \mathrm{MCa}-11$ & 2745.1 & 446.2 & $2.83 \mathrm{E}+01$ & $2.83 \mathrm{E}+04$ & $9.73 \mathrm{E}-01$ & $7.33 \mathrm{E}+01$ \\
\hline 180 & $3 \mathrm{MCa}-12$ & 2957.0 & 480.6 & $2.84 \mathrm{E}+01$ & $2.84 \mathrm{E}+04$ & $9.76 \mathrm{E}-01$ & $7.40 \mathrm{E}+01$ \\
\hline
\end{tabular}

Table A.11. Magnesium Loading Data for 3M Laboratory Cartridge Test Using Simulant

\begin{tabular}{||c|c|c|c|c|c|c|c||}
\hline \hline $\begin{array}{c}\text { Time } \\
(\mathrm{min})\end{array}$ & $\begin{array}{c}\text { Sample } \\
\text { Number }\end{array}$ & $\begin{array}{c}\text { Vol. } \\
(\mathrm{BV})\end{array}$ & $\begin{array}{c}\text { Vol. } \\
(\mathrm{L})\end{array}$ & $\begin{array}{c}\text { Magnesium } \\
(\mathrm{mg} / \mathrm{L})\end{array}$ & $\begin{array}{c}\text { Magnesium } \\
(\mu \mathrm{g} / \mathrm{L})\end{array}$ & $\begin{array}{c}\text { Magnesium } \\
\left(\mathrm{C} / \mathrm{C}_{0}\right)\end{array}$ & $\begin{array}{c}\text { Loaded } \\
(\mathrm{mmol} \mathrm{Mg})\end{array}$ \\
\hline \hline 0 & $3 \mathrm{MMg}-\mathrm{Fd}$ & 0.0 & 0.0 & $5.40 \mathrm{E}+00$ & $5.40 \mathrm{E}+03$ & $1.00 \mathrm{E}+00$ & $1.07 \mathrm{E}+02$ \\
\hline 15 & $3 \mathrm{MMg}-01$ & 268.5 & 43.6 & $4.00 \mathrm{E}-01$ & $4.00 \mathrm{E}+02$ & $7.41 \mathrm{E}-02$ & $4.49 \mathrm{E}+00$ \\
\hline 30 & $3 \mathrm{MMg}-02$ & 540.2 & 87.8 & $5.30 \mathrm{E}+00$ & $5.30 \mathrm{E}+03$ & $9.81 \mathrm{E}-01$ & $9.12 \mathrm{E}+00$ \\
\hline 45 & $3 \mathrm{MMg}-03$ & 808.7 & 131.4 & $7.10 \mathrm{E}+00$ & $7.10 \mathrm{E}+03$ & $1.31 \mathrm{E}+00$ & $7.69 \mathrm{E}+00$ \\
\hline 60 & $3 \mathrm{MMg}-04$ & 1072.7 & 174.4 & $6.10 \mathrm{E}+00$ & $6.10 \mathrm{E}+03$ & $1.13 \mathrm{E}+00$ & $5.57 \mathrm{E}+00$ \\
\hline 75 & $3 \mathrm{MMg}-05$ & 1331.1 & 216.4 & $5.70 \mathrm{E}+00$ & $5.70 \mathrm{E}+03$ & $1.06 \mathrm{E}+00$ & $4.70 \mathrm{E}+00$ \\
\hline 90 & $3 \mathrm{MMg}-06$ & 1584.2 & 257.5 & $5.50 \mathrm{E}+00$ & $5.50 \mathrm{E}+03$ & $1.02 \mathrm{E}+00$ & $4.37 \mathrm{E}+00$ \\
\hline 105 & $3 \mathrm{MMg}-07$ & 1833.0 & 297.9 & $5.40 \mathrm{E}+00$ & $5.40 \mathrm{E}+03$ & $1.00 \mathrm{E}+00$ & $4.28 \mathrm{E}+00$ \\
\hline 120 & $3 \mathrm{MMg}-08$ & 2077.2 & 337.6 & $5.40 \mathrm{E}+00$ & $5.40 \mathrm{E}+03$ & $1.00 \mathrm{E}+00$ & $4.28 \mathrm{E}+00$ \\
\hline 135 & $3 \mathrm{MMg}-09$ & 2309.2 & 375.3 & $5.40 \mathrm{E}+00$ & $5.40 \mathrm{E}+03$ & $1.00 \mathrm{E}+00$ & $4.28 \mathrm{E}+00$ \\
\hline 150 & $3 \mathrm{MMg}-10$ & 2529.1 & 411.1 & $5.40 \mathrm{E}+00$ & $5.40 \mathrm{E}+03$ & $1.00 \mathrm{E}+00$ & $4.28 \mathrm{E}+00$ \\
\hline 165 & $3 \mathrm{MMg}-11$ & 2745.1 & 446.2 & $5.40 \mathrm{E}+00$ & $5.40 \mathrm{E}+03$ & $1.00 \mathrm{E}+00$ & $4.28 \mathrm{E}+00$ \\
\hline 180 & $3 \mathrm{MMg}-12$ & 2957.0 & 480.6 & $5.40 \mathrm{E}+00$ & $5.40 \mathrm{E}+03$ & $1.00 \mathrm{E}+00$ & $4.28 \mathrm{E}+00$ \\
\hline \hline
\end{tabular}


Table A.12. Sodium Loading Data for 3M Laboratory Cartridge Test Using Simulant

\begin{tabular}{|c|c|c|c|c|c|c|c||}
\hline $\begin{array}{c}\text { Time } \\
(\mathrm{min})\end{array}$ & $\begin{array}{c}\text { Sample } \\
\text { Number }\end{array}$ & $\begin{array}{c}\text { Vol. } \\
(\mathrm{BV})\end{array}$ & $\begin{array}{c}\text { Vol. } \\
(\mathrm{L})\end{array}$ & $\begin{array}{c}\text { Sodium } \\
(\mathrm{mg} / \mathrm{L})\end{array}$ & $\begin{array}{c}\text { Sodium } \\
(\mu \mathrm{g} / \mathrm{L})\end{array}$ & $\begin{array}{c}\text { Sodium } \\
\left(\mathrm{C} / \mathrm{C}_{0}\right)\end{array}$ & $\begin{array}{c}\text { Loaded } \\
(\mathrm{mmol} \mathrm{Na})\end{array}$ \\
\hline \hline 0 & $3 \mathrm{MNa}-\mathrm{Fd}$ & 0.0 & 0.0 & $3.60 \mathrm{E}+00$ & $3.60 \mathrm{E}+03$ & $1.00 \mathrm{E}+00$ & $7.53 \mathrm{E}+01$ \\
\hline 15 & $3 \mathrm{MNa}-01$ & 268.5 & 43.6 & $5.25 \mathrm{E}+01$ & $5.25 \mathrm{E}+04$ & $1.46 \mathrm{E}+01$ & $-4.64 \mathrm{E}+01$ \\
\hline 30 & $3 \mathrm{MNa}-02$ & 540.2 & 87.8 & $2.97 \mathrm{E}+01$ & $2.97 \mathrm{E}+04$ & $8.25 \mathrm{E}+00$ & $-1.18 \mathrm{E}+02$ \\
\hline 45 & $3 \mathrm{MNa}-03$ & 808.7 & 131.4 & $1.19 \mathrm{E}+01$ & $1.19 \mathrm{E}+04$ & $3.31 \mathrm{E}+00$ & $-1.51 \mathrm{E}+02$ \\
\hline 60 & $3 \mathrm{MNa}-04$ & 1072.7 & 174.4 & $7.50 \mathrm{E}+00$ & $7.50 \mathrm{E}+03$ & $2.08 \mathrm{E}+00$ & $-1.62 \mathrm{E}+02$ \\
\hline 75 & $3 \mathrm{MNa}-05$ & 1331.1 & 216.4 & $6.40 \mathrm{E}+00$ & $6.40 \mathrm{E}+03$ & $1.78 \mathrm{E}+00$ & $-1.69 \mathrm{E}+02$ \\
\hline 90 & $3 \mathrm{MNa}-06$ & 1584.2 & 257.5 & $5.90 \mathrm{E}+00$ & $5.90 \mathrm{E}+03$ & $1.64 \mathrm{E}+00$ & $-1.73 \mathrm{E}+02$ \\
\hline 105 & $3 \mathrm{MNa}-07$ & 1833.0 & 297.9 & $5.70 \mathrm{E}+00$ & $5.70 \mathrm{E}+03$ & $1.58 \mathrm{E}+00$ & $-1.77 \mathrm{E}+02$ \\
\hline 120 & $3 \mathrm{MNa}-08$ & 2077.2 & 337.6 & $5.50 \mathrm{E}+00$ & $5.50 \mathrm{E}+03$ & $1.53 \mathrm{E}+00$ & $-1.80 \mathrm{E}+02$ \\
\hline 135 & $3 \mathrm{MNa}-09$ & 2309.2 & 375.3 & $5.20 \mathrm{E}+00$ & $5.20 \mathrm{E}+03$ & $1.44 \mathrm{E}+00$ & $-1.83 \mathrm{E}+02$ \\
\hline 150 & $3 \mathrm{MNa}-10$ & 2529.1 & 411.1 & $5.10 \mathrm{E}+00$ & $5.10 \mathrm{E}+03$ & $1.42 \mathrm{E}+00$ & $-1.86 \mathrm{E}+02$ \\
\hline 165 & $3 \mathrm{MNa}-11$ & 2745.1 & 446.2 & $5.00 \mathrm{E}+00$ & $5.00 \mathrm{E}+03$ & $1.39 \mathrm{E}+00$ & $-1.88 \mathrm{E}+02$ \\
\hline 180 & $3 \mathrm{MNa}-12$ & 2957.0 & 480.6 & $4.90 \mathrm{E}+00$ & $4.90 \mathrm{E}+03$ & $1.36 \mathrm{E}+00$ & $-1.90 \mathrm{E}+02$ \\
\hline \hline
\end{tabular}

Table A.13. Strontium-90 Loading Data for PADU Cartridge Field Demonstration at N-Springs

\begin{tabular}{||c|c|r|r|c|c|c|c||}
\hline $\begin{array}{c}\text { Time } \\
(\mathrm{min})\end{array}$ & $\begin{array}{c}\text { Sample } \\
\text { Number }\end{array}$ & $\begin{array}{c}\text { Vol. } \\
(\mathrm{BV})\end{array}$ & $\begin{array}{c}\text { Vol. } \\
(\mathrm{L})\end{array}$ & $\begin{array}{c}\text { Strontium } \\
(\mathrm{pCi} / \mathrm{mL})\end{array}$ & $\begin{array}{c}\text { Strontium } \\
(\mathrm{pCi} / \mathrm{L})\end{array}$ & $\begin{array}{c}\text { Strontium } \\
\left(\mathrm{C} / \mathrm{C}_{0}\right)\end{array}$ & $\begin{array}{c}\text { Loaded } \\
(\mathrm{pCi})\end{array}$ \\
\hline \hline 0 & C3Sr9-Fd & 0.0 & 0.0 & $1.32 \mathrm{E}+00$ & $1.32 \mathrm{E}+03$ & $1.00 \mathrm{E}+00$ & $1.06 \mathrm{E}+06$ \\
\hline 6 & C3Sr9-01 & 170.5 & 83.2 & $4.00 \mathrm{E}-02$ & $4.00 \mathrm{E}+01$ & $3.03 \mathrm{E}-02$ & $5.32 \mathrm{E}+04$ \\
\hline 16 & C3Sr9-02 & 449.6 & 219.2 & $7.80 \mathrm{E}-02$ & $7.80 \mathrm{E}+01$ & $5.91 \mathrm{E}-02$ & $2.25 \mathrm{E}+05$ \\
\hline 31 & C3Sr9-03 & 837.2 & 408.2 & $2.99 \mathrm{E}-01$ & $2.99 \mathrm{E}+02$ & $2.27 \mathrm{E}-01$ & $4.39 \mathrm{E}+05$ \\
\hline 46 & C3Sr9-04 & 1255.8 & 612.4 & $4.82 \mathrm{E}-01$ & $4.82 \mathrm{E}+02$ & $3.65 \mathrm{E}-01$ & $6.28 \mathrm{E}+05$ \\
\hline 61 & C3Sr9-05 & 1643.4 & 801.4 & $6.50 \mathrm{E}-01$ & $6.50 \mathrm{E}+02$ & $4.92 \mathrm{E}-01$ & $7.71 \mathrm{E}+05$ \\
\hline
\end{tabular}




\section{Distribution}

No. of

Copies

OFFSITE

2 DOE/Office of Scientific and Technical Information

G. Allen

Department 6607/MS 0756

Sandia National Laboratories

P.O. Box 5800

Albuquerque, NM 87185-0756

D. H. Bandy

U.S. Department of Energy

P.O. Box 5400

Albuquerque, NM 87115

J. E. Baublitz, EM-40

DOE/Office of Environmental

Restoration

Forrestal Building

U.S. Department of Energy

1000 Independence Ave. SW

Washington, DC 20585

J. P. Bibler

Westinghouse Savannah River Co.

Building $773 \mathrm{~A}$

Aiken, SC 29802

2 W. W. Bixby, EM-60

DOE/Office of the Deputy Assistant

Secretary Facility

Transition and Management

U.S. Department of Energy

1000 Independence Ave. SW

Washington, DC 20585

N. E. Brown

6608 Loftus, NE

Albuquerque, NM 87109
No. of

Copies

R. L. Bruening

505 East 1860 South

IBC Advanced Technologies, Inc.

American Fork, UT· 84603

J. Corones

Ames Laboratory

329 Wilhelm Hall

Iowa State University

Ames, IA 50011

R. Craig

HAZWRAP

P.O. Box 2003, MS 7606

Oak Ridge, TN 37831-7606

6 DOE/Office of Technology Development

Trevion II Building

12800 Middlebrook Road

Germantown, MD 20874

ATTN: G. G. Boyd

EM-50

S. T. Lien

EM-53

R. T. Parker

EM-52

P. J. Ritzcovan

EM-542

W. C. Schutte

EM-54

S. M. Wolfe

EM-532

5 DOE/Office of Waste Management

Trevion II Building

12800 Middlebrook Road

Germantown, MD 20874

ATTN: J. O. Boda

EM-32

J. A. Coleman

EM-35

S. P. Cowan

EM-30

S. L. Domotor

EM-35

H. F. Walter

Distr.1 
No. of

Copies

N. Egan

Program Development Division

MSE Inc.

P.O. Box 3767

Butte, MT 59702

D. Emilia

Strategic Planning Dept.

Chem-Nuclear Geotech

P.O. Box 1400

2597B-3/4 Road (81503)

Grand Junction, CO 81502-2567

B. Erdal

Los Alamos National Laboratory

MS D446

Los Alamos, NM 87545

D. J. Fennelly

UOP Corp.

307 Fellowship Road

Suite 207

Mt. Laurel, NJ 08054

2 J. J. Fiore, EM-42

DOE/Office of Environmental

Restoration

Trevion II Building

12800 Middlebrook Road

Germantown, MD 20874

C. W. Frank, EM-50

DOE/Office of Technology Development

Forrestal Building

U.S. Department of Energy

1000 Independence Ave. SW

Washington, DC 20585

E. Franz

Brookhaven National Laboratory

Building 830

Upton, NY 11973
No. of

Copies

K. D. Gerdes, EM-532

DOE/Office of Technology Development

19901 Germantown Road

Germantown, MD 20874

J. E. Helt

Office of Waste Management Programs

9700 South Cass Avenue

Argonne, IL 60439-4837

R. Jacobson

Desert Research Institute

P.O. Box 19040

Las Vegas, NV 89132

3 T. M. Kafka

3M Center

Bldg. 209-1W-24

St. Paul, MN 55144-1000

K. Kibbe

Martin Marietta Energy Systems

P.O. Box 2003

Bldg. K-1011, MS 7172

Highway 58

Oak Ridge, TN 37831-7172

K. Kostelnik

EG\&G Idaho, Inc., MS 3930

P.O. Box 1625

200 South Woodruff

Idaho Falls, ID 83415-3970

J. E. Lytle, EM-30

DOE/Office of Waste Operations

Forrestal Building

U.S. Department of Energy

1000 Independent Ave. SW

Washington, DC 20585

J. F. McGlynn

SAIC

555 Quince Orchard Road, Suite 500

Gaithersburg, MD 20878

Distr.2 
No. of

Copies

K. McWilliam

U.S. Department of Energy

Nevada Operations Office

P.O. Box 98518

Las Vegas, NV 89109

J. Moore

U.S. Department of Energy

Oak Ridge Operations Office

P.O. Box E

Oak Ridge, TN 37831

K. Nuhfer

FERMCO

P.O. Box 398704

Cincinnati, OH 45239-8704

9 Oak Ridge National Laboratory

P.O. Box 2008

Oak Ridge, TN 378731-6223

ATTN: J. B. Berry

MS-6044

J. L. Collins

MS-6221

B. Z. Egan

MS-6223

R. D. Hunt

MS-6273

D. Lee

MS-6221

A. P. Malinauskas

C. P. McGinnis

J. F. Walker

J. S. Watson

MS-7271

MS-6273

MS-6149

MS-6149

D. Olona

U.S. Department of Energy

Albuquerque Operations office

P.O. Box 5400

Albuquerque, NM 87115

B. Park

MSE Inc.

P.O. Box 4078

Butte, MT 59702
No. of

Copies

P. J. Pettit

P.O. Box 538704

Mailstop 81-2

Cincinnati, OH 45253-8704

R. W. Rice

MSE, Inc.

307 Quincy

El Paso, TX 79922

2 Sandia National Laboratories

P.O. Box 5800

Albuquerque, NM 87185-5800

ATTN: J. E. Miller

MS-0709

J. Nelson

MS-6621

G. Staats

U.S. Department of Energy

Pittsburgh Energy Technology Center

P.O. Box 10940

Pittsburgh, PA 15236-0940

J. L. Steele

Savannah River Site

SRL, 773 A, A208

Aiken, SC 29802

S. L. Stein

Battelle Seattle Research Center

4000 NE 41st Street

Seattle, WA 98105

K. Stevenson

U.S. Department of Energy

376 Hudson Street

New York, NY 10014-3621

J. L. Swanson

1318 Cottonwood Drive

Richland, WA 99352 
No. of

Copies

J. Sweeney

U.S. Department of Energy

Oak Ridge Operations Office

P.O. Box E

Oak Ridge, TN 37831

I. R. Tasker

Waste Policy Institute

Quince Diamond Executive Center

555 Quince Orchard Road

Gaithersburg, MD 20878-1437

M. C. Thompson

Savannah River Technology Center

P.O. Box 616

Aiken, SC 29802

2 T. A. Todd

Lockheed Idaho Technology Company

P.O. Box 1625, MS 5213

Idaho Falls, ID 83415

C. Tsang

Earth Sciences Division

Bldg. 50E

Lawrence Berkeley Laboratory

Berkeley, CA 94720

S. Turner

BNFL

2261 Stevens Drive

Richland, WA 99352

UOP Corp.

50 East Algonquin

Des Plaines, IL 60017-5016

ATTN: J. Sherman

R. Braun

S. Webster

U.S. Department of Energy

Chicago Field Office

9800 South Cass Avenue

Argonne, IL 60439-4837
No. of

Copies

T. Williams

U.S. Department of Energy

Idaho Operations Office

785 DOE Place

Idaho Falls, ID 83402

J. Wright

U.S. Department of Energy

Savannah River Operations Office

RFD \#1, Bldg. 703A, Rm. E208 North

P.O. Box A

Aiken, SC 29802

S. Yates

AlliedSignal

50 East Algonquin Road

Des Plaines, IL 60017-5016

J. Yow

Lawrence Livermore National

Laboratory

7000 East Avenue

P.O. Box 808

Livermore, CA 94550

C. Zeh

Morgantown Energy Technology Center 3610 Collins Ferry Road

Morgantown, WV 26507-0880

\section{ONSITE}

\section{DOE Richland Operations Office}
J. A. Frey
K8-50
J. P. Hanson
K8-50
P. E. Lamont
S7-53
C. S. Louie
S7-53
B. M. Mauss
K8-50
D. E. Trader
K8-50
L. S. Walder
S7-53 
No. of

Copies

7 Bechtel Hanford, Incorporated
A. G. Duda
HO-18
M. H. Hyman
S. A. Hobart
K. J. Koegler
S. Kretzschmar
M. J. Lauterbach
S. K. Pulsford
$\mathrm{H} 4-80$
H4-80
$\mathrm{H} 0-18$
X5-54
$X 5-54$
$\mathrm{X} 5-53$

2 CH2M Hill Hanford, Inc.

T. E. Moody

H9-03

D. J. Vaught

H9-01

\section{MACTEC}

D. J. Swanberg

K8-50

15 Westinghouse Hanford Company

J. N. Appel

G3-21

S. A. Barker

W. B. Barton

G. T. Berlin

J. D. Berger

M. D. Britton

K. M. Eager

K. A. Gasper

D. L. Herting

C. V. King

R. A. Kirkbride

M. J. Klem

D. L. Penwell

I. E. Reep

D. J. Washenfelder
No. of

Copies

46 Pacific Northwest National Laboratory

J. E. Amonette K9-77

W. F. Bonner K9-14

L. A. Bray P7-25

K. P. Brooks P7-43

T. M. Brouns K9-08

G. N. Brown (10) P7-25

G. H..Bryan P7-25

S. A. Bryan P7-25

B. C. Bunker K2-45

K. J. Carson P7-25

C. D. Carison P7-25

R. J. Elovich P7-25

J. A. Franz K2-44

J. M. Gephart K2-21

L. K. Holton $\quad$ K9-73

T. L. Hubler P8-38

W. L. Kuhn K2-21

D. E. Kurath P7-20

J. P. LaFemina K2-25

M. E. Peterson K2-47

R. K. Quinn $\quad$ K9-69

W. G. Richmond K9-33

L. J. Sealock K2-10

J. T. Slankas K9-81

S. O. Slate

Technical Report Files (5)

PNL Information Release

Office (7)
P8-44

K1-11 